\title{
Regulação de produtos derivados do tabaco pela Anvisa
}

\author{
Supremo Tribunal Federal (STF)
}

\section{Ação Direta de Inconstitucionalidade 4.874 Distrito Federal}

\section{Voto}

1. Considerações iniciais. 2. Pedido principal. 2.1. Dispositivos impugnados. 2.2. Conhecimento do pedido principal. 2.3. Mérito. 2.3.1. O Sistema Nacional de Vigilância Sanitária e a ANVISA. 2.3.2. Regulação setorial e competência normativa. 2.3.3. Regulação e regulamentação: distinções necessárias. 2.3.4. O princípio da legalidade na regulação setorial. 2.3.5. Limites materiais do poder normativo. 2.3.6. As competências previstas nos incisos III e XV do art. $7^{\circ}$ da Lei $\mathrm{n}^{\mathrm{o}}$ 9.782/1999. 2.3.6.1. Art. $7^{\circ}$, XV, da Lei no 9.782/1999. 2.3.6.2. Art. 7º, III, da Lei no 9.782/1999. 3. Pedido sucessivo. 3.1. Conhecimento. 3.2. Mérito. 3.2.1. A cláusula constitucional do direito à saúde. 3.2.2. Restrições aos produtos derivados do tabaco previstas no ordenamento jurídico brasileiro. 3.2.3. Sujeição dos produtos fumígenos à regulação setorial exercida pela ANVISA. 3.2.4. A Convenção-Quadro sobre Controle do Uso do Tabaco - CQCT. 3.2.5. Nota sobre a restrição de direitos fundamentais no Estado democrático de direito. 3.2.6. Contribuição do direito comparado. 3.2.7. Constitucionalidade da Resolução da Diretoria Colegiada no 14/2012 da ANVISA. 4. Conclusão. 
A Senhora Ministra Rosa Weber (Relatora): Senhora Presidente, Egrégio Plenário, saúdo todos, e em especial os amici curiae que acorreram ao processo em número expressivo, com contribuições de valor inestimável, sob múltiplas formas e com riqueza de conteúdo, via memoriais, documentos oficiais, relatórios, estatísticas, obras acadêmicas, resultados de pesquisas científicas, além de pareceres da mais alta qualidade, de lavra ilustre, dentre outros, do Ministro Sepúlveda Pertence e do Ministro Luís Roberto Barroso, antes de ocupar o cargo de Ministro desta Corte, e ainda dos Professores José Torquato, Gomes Canotilho, Jónatas Machado, José Augusto Delgado, Virgílio Afonso da Silva e Luís Renato Vedovato.

A pluralidade de argumentos, pontos de vista, informações e dados técnicos disponibilizados certamente concorreu para o aprofundamento da compreensão do substrato fático e social sobre o qual transita a presente controvérsia, ampliando o horizonte da reflexão quanto aos relevantes temas de natureza constitucional que desafia.

\section{Considerações iniciais}

Como relatei, a presente ação direta discute a higidez constitucional do art. $7^{\circ}$, III e XV, parte final, da Lei no 9.782/1999 - lei definidora do Sistema Nacional de Vigilância Sanitária e instituidora da Agência Nacional de Vigilância Sanitária, a ANVISA. Questiona-se, também, de forma sucessiva, a validade constitucional da Resolução da Diretoria Colegiada (RDC) da ANVISA no 14/2012 em sua integralidade.

A Confederação Nacional da Indústria, autora desta ação de controle concentrado, submete à jurisdição constitucional desta Casa, em última análise, como questão central, a definição dos contornos e limites da função normativa exercida pelas chamadas agências reguladoras, em particular pela Agência Nacional de Vigilância Sanitária, a ANVISA.

O pano de fundo da discussão é a iniciativa da ANVISA de proibir a importação e a comercialização no país de produtos fumígenos derivados do tabaco que contenham as substâncias ou compostos que define como aditivos.

O vocábulo aditivo, segundo a definição do art. 3ㅜ, I, da $\operatorname{RDC}$ no $^{\mathbf{0}}$ 14/2012, designa "qualquer substância ou composto, que não seja tabaco ou água, utilizado no processamento das folhas de tabaco e do tabaco reconstituído, na fabricação e no acondicionamento de um produto fumígeno derivado do tabaco, incluindo açúcares, adoçantes, edulcorantes, aromatizantes, flavorizantes e ameliorantes". 
Alcança, assim, conjuntos de substâncias e compostos, naturais ou sintéticos, que confiram, modifiquem, melhorem ou intensifiquem sabor ou aroma em produto fumígeno derivado do tabaco ou reduzam características desagradáveis da fumaça por ele produzida. De modo geral, os aditivos são utilizados tanto para tornar o produto mais atraente ao consumidor quanto para definir e acentuar propriedades e características associadas à identidade de diferentes variedades e marcas de produtos.

Na nota técnica "Aditivos em Cigarros", de 11 de outubro de 2010, trazida aos autos pelo amicus curiae Associação de Controle do Tabagismo, Promoção da Saúde e dos Direitos Humanos - ACT, e elaborada em conjunto pela Secretaria Executiva da Comissão Nacional para Implementação da Convenção-Quadro para o Controle do Tabaco, pelo Instituto Nacional de Câncer - INCA e pelo Ministério da Saúde, os aditivos aos cigarros são caracterizados como tecnologias que visam a aumentar a capacidade de causar dependência química e a atratividade dos produtos, além de facilitar a experimentação entre adolescentes. No documento, é destacado que “alguns desses ingredientes, como, por exemplo, o açúcar, além de ter o objetivo de melhorar o sabor e a sensação de irritação causada pela fumaça do cigarro, também atua potencializando a capacidade de o produto causar dependência e que alguns desses aditivos após a combustão se transformam em substâncias tóxicas e cancerígenas".

\section{Pedido principal}

O pedido principal deduzido na ação é de que se empreste ao art. $\mathbf{7}^{\mathbf{0}}, \mathbf{X V}$, in fine, da Lei no 9.782/1999 - com a alternativa de invocação, para o mesmo efeito, do inciso III desse mesmo dispositivo - interpretação conforme a Constituição, sem redução de texto, para fixar a exegese de que "a ANVISA só poderá banir produto ou insumo no exercício de suas competências estritamente executivas de polícia, de natureza cautelar e excepcional, o que implica dizer deva o ato da Agência: (i) ser direcionado a sujeitos e situações determinadas, (ii) em situações concretas, (iii) mediante prévia justificação técnica que comprove (iv) um risco à saúde que seja extraordinário, excepcional e urgente".

Requerida, em decorrência, a declaração de inconstitucionalidade, por arrastamento, da Resolução da Diretoria Colegiada (RDC) no 14/2012 da Agência Nacional de Vigilância Sanitária - ANVISA. 


\subsection{Dispositivos impugnados}

Eis o teor dos dispositivos da Lei no 9.782/1999 objeto do pedido de interpretação conforme a Constituição veiculado na presente ação direta:

Art. $7^{\circ}$ Compete à Agência proceder à implementação e à execução do disposto nos incisos II a VII do art. $2^{\mathrm{o}}$ desta Lei, devendo:

$[\ldots]$

III - estabelecer normas, propor, acompanhar e executar as políticas, as diretrizes e as ações de vigilância sanitária;

$[\ldots]$

XV - proibir a fabricação, a importação, o armazenamento, a distribuição e a comercialização de produtos e insumos, em caso de violação da legislação pertinente ou de risco iminente à saúde; [destaquei]

O art. $2^{\mathrm{o}}$ da Lei $\mathbf{n}^{\mathbf{0}}$ 9.782/1999, a cujos incisos II a VII remete o caput do dispositivo transcrito, por sua vez dispõe:

Art. $2^{\circ}$ Compete à União no âmbito do Sistema Nacional de Vigilância Sanitária:

I - definir a política nacional de vigilância sanitária;

II - definir o Sistema Nacional de Vigilância Sanitária;

III - normatizar, controlar e fiscalizar produtos, substâncias e serviços de interesse para a saúde;

IV - exercer a vigilância sanitária de portos, aeroportos e fronteiras, podendo essa atribuição ser supletivamente exercida pelos Estados, pelo Distrito Federal e pelos Municípios;

V - acompanhar e coordenar as ações estaduais, distrital e municipais de vigilância sanitária;

VI - prestar cooperação técnica e financeira aos Estados, ao Distrito Federal e aos Municípios;

VII - atuar em circunstâncias especiais de risco à saúde; e

VIII - manter sistema de informações em vigilância sanitária, em cooperação com os Estados, o Distrito Federal e os Municípios.

$\S 1^{0}$ A competência da União será exercida: 
I - pelo Ministério da Saúde, no que se refere à formulação, ao acompanhamento e à avaliação da política nacional de vigilância sanitária e das diretrizes gerais do Sistema Nacional de Vigilância Sanitária; II - pela Agência Nacional de Vigilância Sanitária - ANVS, em conformidade com as atribuições que lhe são conferidas por esta Lei; e III - pelos demais órgãos e entidades do Poder Executivo Federal, cujas áreas de atuação se relacionem com o sistema.

§2ํㅡㄹ O Poder Executivo Federal definirá a alocação, entre os seus órgãos e entidades, das demais atribuições e atividades executadas pelo Sistema Nacional de Vigilância Sanitária, não abrangidas por esta Lei.

$\S 3^{o}$ Os Estados, o Distrito Federal e os Municípios fornecerão, mediante convênio, as informações solicitadas pela coordenação do Sistema Nacional de Vigilância Sanitária. [destaquei]

Transcrevo o inteiro teor da Resolução da Diretoria Colegiada - RDC no 14/2012 da ANVISA, igualmente impugnada no feito, destacando os arts. $6^{0}$ e $7^{0}$, cujo conteúdo figura no cerne da controvérsia submetida a esta Corte:

A Diretoria Colegiada da Agência Nacional de Vigilância Sanitária, no uso da atribuição que lhe confere o inciso IV do art. 11 do Regulamento aprovado pelo Decreto n. 3.029, de 16 de abril de 1999, e tendo em vista o disposto no inciso II e nos $\S \S 1^{\circ}$ e $3^{\text {o }}$ do art. 54 do Regimento Interno aprovado nos termos do Anexo I da Portaria n. 354 da Anvisa, de 11 de agosto de 2006, republicada no DOU de 21 de agosto de 2006, em reunião realizada em 13 de março de 2012, adota a seguinte Resolução de Diretoria Colegiada e eu, Diretor-Presidente, determino a sua publicação:

Art. $1^{\circ}$ Ficam estabelecidos os limites máximos de alcatrão, nicotina e monóxido de carbono na corrente primária da fumaça dos cigarros e a restrição do uso de aditivos em todos os produtos fumígenos derivados do tabaco comercializados no Brasil, nos termos desta Resolução.

CAPÍTULO I

DAS DISPOSIÇÕES INICIAIS

Seção I Abrangência

Art. $2^{\circ}$ Esta Resolução se aplica aos produtos fumígenos derivados do tabaco comercializados no país, de fabricação nacional ou importados. 


\section{Seção II Definições}

Art. $3^{\text {o }}$ Para efeito desta Resolução, são adotadas as seguintes definições: I - aditivo: qualquer substância ou composto, que não seja tabaco ou água, utilizado no processamento das folhas de tabaco e do tabaco reconstituído, na fabricação e no acondicionamento de um produto fumígeno derivado do tabaco, incluindo açúcares, adoçantes, edulcorantes, aromatizantes, flavorizantes e ameliorantes;

II - açúcares: monossacarídeos e dissacarídeos, incluindo a sacarose obtida a partir do caldo de cana-de-açúcar (Saccharum officinarum L.) ou de beterraba (Beta alba L.), podendo apresentar-se em diversas granulometrias e formas de apresentação;

III - adoçante: produto constituído de edulcorante(s), podendo conter outro(s) ingrediente(s), que confere sabor doce ao produto fumígeno derivado do tabaco;

IV - ameliorante: substância que reduz os aspectos irritantes da fumaça de produtos fumígenos derivados do tabaco;

V - aromatizante: substância natural ou sintética ou mistura de substâncias que confere, modifica, melhora ou intensifica aroma em produtos fumígenos derivados do tabaco;

VI - corrente primária: fumaça que sai da extremidade do produto fumígeno que vai à boca e aspirada pelo fumante durante o processo de fumada, também denominada fumaça principal;

VII - edulcorante: substância diferente dos açúcares que confere sabor doce ao produto fumígeno derivado do tabaco;

VIII - embalagem: invólucro, recipiente ou qualquer forma de acondicionamento destinado a conter os produtos fumígenos derivados do tabaco;

IX - flavorizante: substância natural ou sintética ou mistura de substâncias que confere, modifica, melhora ou intensifica sabor e aroma em produtos fumígenos derivados do tabaco;

$X$ - produto fumígeno: produto manufaturado, derivado do tabaco ou não, que contém folhas ou extratos de folhas ou outras partes de plantas em sua composição; e

XI - produto fumígeno derivado do tabaco: qualquer produto manufaturado derivado do tabaco, que contém em sua composição folhas de tabaco, ainda que seja parcialmente constituído por tabaco. 


\section{CAPÍTULO II}

\section{DOS LIMITES MÁXIMOS DE ALCATRÃO, NICOTINA E MONÓXIDO DE CARBONO NOS CIGARROS}

Art. $4^{\underline{0}}$ Nos cigarros comercializados no Brasil, os limites máximos permitidos de alcatrão, nicotina e monóxido de carbono na corrente primária da fumaça são:

I - alcatrão: $10 \mathrm{mg} /$ cigarro (dez miligramas por cigarro);

II - nicotina: $1 \mathrm{mg} /$ cigarro (um miligrama por cigarro); e

III - monóxido de carbono: $10 \mathrm{mg} /$ cigarro (dez miligramas por cigarro).

$\S 1^{\circ}$ Os limites máximos estabelecidos no caput referem-se ao teor médio determinado por análise laboratorial quantitativa, acrescidos dos respectivos desvios-padrão analíticos.

$\S 2^{\circ}$ Nas quantificações dos teores, devem ser utilizadas quaisquer metodologias analíticas aceitas internacionalmente ou aquelas adotadas por força de lei, acordo ou convênio internacional ratificado e internalizado pelo Brasil.

CAPÍTULO III

\section{DAS EXPRESSÕES NAS EMBALAGENS}

Art. 5ํㅜ Fica proibida, em embalagens de todos os produtos fumígenos derivados do tabaco, a utilização de qualquer expressão que possa induzir o consumidor a uma interpretação equivocada quanto aos teores contidos nestes produtos, como: classe(s), ultrabaixo(s) teor(es), baixo(s) teor(es), suave, light, soft, leve, teor(es) moderado(s), alto(s) teor(es), dentre outras.

CAPÍTULO IV

DOS ADITIVOS

Art. $6^{0}$ Ficam proibidas a importação e a comercialização no país de produto fumígeno derivado do tabaco que contenha qualquer um dos seguintes aditivos:

I - substâncias sintéticas e naturais, em qualquer forma de apresentação (substâncias puras, extratos, óleos, absolutos, bálsamos, dentre outras), com propriedades flavorizantes ou aromatizantes que possam conferir, intensificar, modificar ou realçar sabor ou aroma do produto, incluindo os aditivos identificados como agentes aromatizantes ou flavorizantes: 
a) pelo Joint FAO/WHO Expert Committee on Food Additives JECFA (Comitê Conjunto da Organização das Nações Unidas para a Agricultura e Alimentação (FAO) / Organização Mundial da Saúde (OMS) de Especialistas em Aditivos Alimentares); ou

b) pela Flavor and Extract Manufacturers Association - FEMA (Associação dos Fabricantes de Aromas e Extratos).

II - coadjuvantes de tecnologia (ou auxiliares de processo) para aromatizantes e flavorizantes;

III - aditivos com propriedades nutricionais, incluindo:

a) aminoácidos;

b) vitaminas;

c) ácidos graxos essenciais; $\mathrm{e}$

d) minerais, exceto aqueles comprovadamente essenciais para a fabricação dos produtos derivados do tabaco.

IV - aditivos associados com alegadas propriedades estimulantes ou revigorantes, incluindo taurina, guaraná, cafeína e glucuronolactona; V - pigmentos (ou corantes);

VI - frutas, vegetais ou qualquer produto originado do processamento de frutas e vegetais, exceto carvão ativado e amido;

VII - adoçantes, edulcorantes, mel, melado ou qualquer outra substância que possa conferir aroma ou sabor doce, diferente de açúcares; VIII - temperos, ervas e especiarias ou qualquer substância que possa conferir aroma ou sabor de temperos, ervas e especiarias;

IX - ameliorantes; e

$X$ - amônia e todos os seus compostos e derivados.

Art. $7^{0}$ Fica permitida a utilização dos seguintes aditivos em produtos fumígenos derivados do tabaco:

I - açúcares, exclusivamente para recomposição do teor de açúcar presente originalmente na folha de tabaco antes do processo de secagem;

II - adesivos;

III - agentes aglutinantes;

IV - agentes de combustão;

V - coadjuvantes de tecnologia (ou auxiliares de processo) que não sejam para aromatizantes e flavorizantes; 
VI - pigmentos (ou corantes) utilizados no branqueamento do papel ou do filtro, para imitar o padrão de cortiça no envoltório da ponteira e aqueles utilizados para impressão de logotipos ou marcas;

VII - glicerol e propilenoglicol; e

VIII - sorbato de potássio.

\$1 $1^{\circ} \mathrm{A}$ adição de açúcares prevista no inciso I fica condicionada à declaração das perdas e da necessidade de reposição, a ser apresentada pelas empresas no ato do peticionamento de Registro ou Renovação de Registro de Produto Fumígeno Derivado do Tabaco - Dados Cadastrais ou de Alteração de Dados.

\$2 $2^{\circ}$ A Diretoria Colegiada poderá, mediante ato normativo próprio, aprovar o uso de outros aditivos, considerando as justificativas apresentadas pelas empresas quanto à sua necessidade para o produto fumígeno derivado do tabaco, desde que não alterem seu sabor ou aroma.

\section{CAPÍTULO V}

\section{DAS DISPOSIÇÕES FINAIS E TRANSITÓRIAS}

Art. $8^{\circ}$ Fica concedido o prazo de 18 (dezoito) meses, a contar da data da publicação desta Resolução, para que as empresas fabricantes e importadoras de produtos fumígenos derivados do tabaco que já detenham Registro de Produto Fumígeno - Dados Cadastrais atendam ao disposto no artigo $5^{\circ}$.

\$1 $1^{\circ}$ Findo o prazo referido no caput, os produtos que não estejam em conformidade com o artigo $5^{\circ}$ poderão ser comercializados no comércio varejista pelo prazo de 6 (seis) meses.

$\S 2^{\circ}$ Findo o prazo estabelecido no $\$ 1^{\circ}$, os produtos deverão ser recolhidos do comércio pelos fabricantes, importadores, distribuidores e comerciantes.

$\S^{3}$ O Os prazos dispostos neste artigo não se aplicam aos cigarros.

Art. 9 Fica concedido o prazo de 18 (dezoito) meses, a contar da data da publicação desta Resolução, para que as empresas fabricantes e importadoras de produtos fumígenos derivados do tabaco que já detenham Registro de Produto Fumígeno - Dados Cadastrais atendam ao disposto no artigo $6^{\circ}$.

$\S 1^{0}$ Findo o prazo referido no caput, os produtos que não estejam em conformidade com o artigo $6^{\circ}$ poderão ser comercializados no comércio varejista pelo prazo de 6 (seis) meses. 
$\S 2^{\circ}$ Findo o prazo estabelecido no $\S 1^{\circ}$, os produtos deverão ser recolhidos do comércio pelos fabricantes, importadores, distribuidores e comerciantes.

Art. 10. Qualquer alteração na composição, na embalagem ou no nome da marca do produto, para fins de cumprimento dos artigos $5^{0}$ e $6^{0}$ desta Resolução, deverá ser realizada por meio de petição de Alteração de Dados ou petição de Renovação de Registro de Produto Fumígeno - Dados Cadastrais.

Art. 11. O descumprimento das disposições contidas nesta Resolução constitui infração sanitária, nos termos da Lei n. 6.437, de 20 de agosto de 1977, sem prejuízo das responsabilidades civil, administrativa e penal cabíveis.

Art. 12. Fica revogada a Resolução RDC n. 46, de 28 de março de 2001.

Art. 13. Esta Resolução de Diretoria Colegiada entra em vigor na data de sua publicação. [destaquei]

\subsection{Conhecimento do pedido principal}

Impugnados dispositivos de lei ordinária federal (art. 102, I, "a", da Constituição da República), presente a legitimidade ativa ad causam da requerente (arts. 103, IX, da CF e $\mathbf{2}^{\circ}$, IX, da Lei no ${ }^{9.868 / 1999)}$ e atendidos os requisitos do art. $3^{0}$ da Lei $\mathbf{n}^{0}$ 9.868/1999, conheço do pedido de interpretação conforme a Constituição do art. $7^{\circ}, \mathrm{XV}$, in fine, da Lei ${ }^{\circ}$ 9.782/1999 e, alternativamente, do inciso III do mesmo art. $7^{\circ}$.

\subsection{Mérito}

Ao enfrentamento do mérito, permito-me lembrar, de início, pela pertinência, as palavras de Sandra Day O'Connor, Juíza hoje aposentada da Suprema Corte dos EUA, em julgamento paradigmático daquela Casa (Food and Drug Administration v. Brown \& Williamson Tobacco Corporation), em que enfrentados dilemas análogos aos ora submetidos a este Supremo Tribunal Federal: "este caso envolve um dos mais preocupantes problemas de saúde pública enfrentados hoje pela nossa nação - as milhares de mortes prematuras que ocorrem a cada ano devido ao uso do tabaco". 
De fato, segundo relatório da Organização Mundial de Saúde - OMS divulgado em 2008, o uso do tabaco foi a causa de cerca de 100 milhões de mortes prematuras no decorrer do século XX. No último relatório global sobre tendências na prevalência do tabagismo, divulgado em 2015, esse organismo internacional aponta para seis milhões de mortes anuais provocadas pelo uso do tabaco, incluídas nesse número as estimadas seiscentas mil mortes causadas pela exposição passiva aos efeitos do fumo. ${ }^{1}$

O conjunto de evidências científicas hoje disponível autoriza qualificar de incontestável, porque não exposta a margem razoável de dúvida, a premissa fática de que o consumo do tabaco acarreta prejuízos de elevada magnitude à saúde dos seus usuários. Trata-se de fato que, na presente quadra da história, não está sequer aberto à discussão.

Sobre a prática do fumo do tabaco, também já foi dito que seria a atividade voluntária mais perigosa do mundo, ${ }^{2}$ afirmação não isenta de controvérsia por deixar de considerar adequadamente o problema da relação entre a autonomia individual e o comportamento condicionado por dependência química ou psicológica. Ainda que a decisão de começar a fumar, desde que consciente e informada, possa ser considerada livre, frequentemente, e quiçá no mais das vezes, não se pode assumir como livre a vontade do indivíduo quando se trata de escolher entre seguir fumando ou abandonar o vício.

A Associação Médica Brasileira - em Carta Aberta a este STF, datada de 17.11.2016 — , ao externar considerações técnicas sobre o tema baseadas em robustas evidências científicas, alerta que o tabagismo é uma doença que inicia na infância e na adolescência: cerca de oitenta a noventa por cento dos fumantes se tornam dependentes do tabaco antes dos dezoito anos. Por isso, é considerado doença pediátrica.

Há de ser especialmente reconhecida, nesse quadro, a importância da adoção, pelos governos, de medidas políticas voltadas ao controle do tabagismo. No Brasil, o sucesso da progressiva implementação de políticas públicas orientadas ao controle do tabagismo é evidenciado pela substancial redução da população fumante, que, segundo dados fornecidos pelo Instituto Nacional do Câncer - INCA, caiu de 34,8\% (trinta e quatro inteiros e oito décimos por cento) da população adulta em 1989 para 14,7\% (quatorze inteiros

WHO global report on trends in prevalence of tobacco smoking 2015. World Health Organization, 2015.

2 Revista The Economist, 23.3.2013. 
e sete décimos por cento) em 2013, ${ }^{3}$ o que se traduz em aproximadamente meio milhão de mortes evitadas no período. ${ }^{4}$ Em 2016, segundo dados do Ministério da Saúde divulgados pelo Observatório da Política Nacional de Controle do Tabaco, esse número passou a 10,2\% (dez inteiros e dois décimos por cento) da população. ${ }^{5}$ Com efeito,

Os problemas decorrentes do consumo do tabaco já foram objeto de preocupação e discussão, inicialmente, pela área médica e de saúde pública. $\mathrm{O}$ que mudou nesse cenário foi a necessidade de o direito vir amparar o crescimento das políticas públicas de combate ao uso do cigarro, seja para os fumantes, seja para proteger os não fumantes da fumaça maligna do tabaco, produzindo um arcabouço jurídico sólido $[\ldots] \cdot{ }^{6}$

Um aspecto peculiar do uso do tabaco merece ser desde logo ressaltado por apresentar dificuldade adicional ao equacionamento de questões relacionadas ao seu controle: o uso lícito, normal e esperado do produto é em si mesmo danoso à saúde do usuário. Os efeitos nocivos ao consumidor não constituem riscos marginais ou laterais, cuja concretização dependa de suposto mau uso, de imperícia, de condições especiais de uso, ou da conjugação com um evento fortuito ou incerto. Tais efeitos nocivos são consequências diretamente esperadas do uso regular do tabaco.

Importante sublinhar, desde logo, que não está em jogo a licitude, no ordenamento jurídico pátrio, do consumo do tabaco e de produtos dele derivados, assim como a licitude de sua produção, comercialização e importação.

Bem situada a questão, vejo como figura de retórica a assertiva lançada da tribuna sobre eventual risco de a ANVISA vir a, por resolução, retirar a folha de tabaco presente no Brasão da República. A propósito, enfatizo que o ramo de fumo florido orna não apenas as Armas Nacionais, em composição

3 Instituto Brasileiro de Geografia e Estatística - IBGE. Pesquisa nacional de saúde 2013. Rio de Janeiro, 2014.

4 Levy, D.; de Almeida, L. M.; Szklo, A. (2012) The Brazil simsmoke policy simulation model: the effect of strong tobacco control policies on smoking prevalence and smoking-attributable deaths in a middle income nation. PLoS Med, 9(11): e1001336. https://doi.org/10.1371/journal. pmed.1001336.

5 Ministério da Saúde. Vigitel Brasil 2016. Brasília, 2017.

6 SOARES, Renata Domingues Balbino Munhoz. Direito e tabaco: prevenção, reparação e decisão. São Paulo: Atlas, 2016. 
com um ramo de café frutificado, como também a própria bandeira do Estado do Rio Grande do Sul, onde se ladeia a um ramo de erva-mate.

A Constituição da República Federativa do Brasil reconhece, a um só tempo, a nocividade do uso do tabaco à saúde e, não obstante, a sua licitude, ainda que por via transversa, ao assentar, no art. $220, \S 4^{\circ}$ :

Art. 220. [...]

$[\ldots]$

$\S 4^{\mathrm{o}}$ - A propaganda comercial de tabaco, bebidas alcoólicas, agrotóxicos, medicamentos e terapias estará sujeita a restrições legais, nos termos do inciso II do parágrafo anterior, e conterá, sempre que necessário, advertência sobre os malefícios decorrentes de seu uso. [destaquei]

Apesar de lícitos, no ordenamento jurídico pátrio, a produção, a comercialização, a importação e o consumo do tabaco e de produtos dele derivados, fumígenos ou não, sequer há necessidade de superar maiores dificuldades hermenêuticas para concluir que o risco à saúde associado a essas atividades justifica a sujeição do seu mercado a intensa regulação sanitária, tendo em vista o interesse público na proteção e na promoção da saúde. E é o que efetivamente ocorre, no âmbito do Sistema Nacional de Vigilância Sanitária.

\subsubsection{O Sistema Nacional de Vigilância Sanitária e a ANVISA}

A atividade regulatória da Administração desempenha, na quase totalidade dos países, papel fundamental na proteção dos direitos e interesses sanitários e da saúde.

A Lei no 9.782/1999 instituiu um verdadeiro sistema de vigilância sanitária, do qual fazem parte a criação da Agência Nacional de Vigilância Sanitária - ANVISA e a definição das suas competências. É como elementos desse sistema, integrantes de uma unidade coesa, e não como apanhado de preceitos isolados e desconexos, que hão de ser interpretados os seus dispositivos. Nessa ótica, reproduzo o art. $1^{0}$ da Lei no $^{\mathbf{0}}$ 9.782/1999:

Art. 1ํ. O Sistema Nacional de Vigilância Sanitária compreende o conjunto de ações definido pelo $\S 1^{\circ}$ do art. $6^{\circ}$ e pelos arts. 15 a 18 da Lei $\mathrm{n}^{\mathrm{o}}$ 8.080, de 19 de setembro de 1990, executado por instituições 
da Administração Pública direta e indireta da União, dos Estados, do Distrito Federal e dos Municípios, que exerçam atividades de regulação, normatização, controle e fiscalização na área de vigilância sanitária.

Já o art. $6^{\circ}$, §1º, da Lei n⿳o 8.080/1990 - Lei do Sistema Único de Saúde, ao qual o art. $1^{\text {o }}$ da Lei $\mathrm{n}^{\mathrm{0}}$ 9.782/1999, transcrito, faz expressa remissão - positiva a definição legal do conceito de vigilância sanitária:

Art. $6^{\circ}[\ldots]$

$\S^{0}$ Entende-se por vigilância sanitária um conjunto de ações capaz de eliminar, diminuir ou prevenir riscos à saúde e de intervir nos problemas sanitários decorrentes do meio ambiente, da produção e circulação de bens e da prestação de serviços de interesse da saúde, abrangendo:

I - o controle de bens de consumo que, direta ou indiretamente, se relacionem com a saúde, compreendidas todas as etapas e processos, da produção ao consumo; e

II - o controle da prestação de serviços que se relacionam direta ou indiretamente com a saúde.

Nos termos do art. 2º, III, da Lei no 9.782/1999, compete à União, no âmbito do Sistema Nacional de Vigilância Sanitária, "normatizar, controlar e fiscalizar produtos, substâncias e serviços de interesse para a saúde". Tais competências, nos moldes dos arts. $2^{\circ}, \$^{\mathbf{0}}$, II, e $7^{\mathbf{0}}$, caput, do referido diploma, serão exercidas pela Agência Nacional de Vigilância Sanitária - ANVISA.

Ocupa, assim, papel central no sistema de vigilância sanitária instituído pela Lei no 9.782/1999 a criação da Agência Nacional de Vigilância Sanitária - ANVISA, instituída na forma de autarquia sob regime especial vinculada ao Ministério da Saúde e caracterizada pela independência administrativa, estabilidade de seus dirigentes e autonomia financeira (art. $\mathbf{3}^{\mathbf{o}}$, caput e parágrafo único).

É o regime jurídico efetivamente delineado na sua lei instituidora, interpretado segundo os parâmetros impostos pela Constituição da República, que confere à Agência Nacional de Vigilância Sanitária os precisos contornos das suas competências. 
$\mathrm{Na}$ espécie, a controvérsia relativa aos limites hermenêuticos do art. $\mathbf{7}^{\mathbf{0}}$, III e XV, parte final, da Lei no 9.782/1999 (pedido de interpretação conforme a Constituição) desafia a delimitação da extensão das funções de polícia e normativas especificamente previstas nos dispositivos de lei impugnados, à luz do parâmetro constitucional.

\subsubsection{Regulação setorial e competência normativa}

Tendo presente a questão central proposta - os contornos e limites do poder normativo das agências reguladoras -, há que precisar alguns conceitos a respeito, para que, afastando a equivocidade das palavras e eventual polissemia, a conclusão não se ressinta da imprescindível clareza.

O escopo da competência normativa das agências reguladoras, bem como suas repercussões sobre os princípios da legalidade, da separação de poderes e da legitimação democrática das decisões políticas, tem sido tema de vasto e rico debate doutrinário no âmbito do direito público contemporâneo. Pode-se afirmar, nesse sentido, que à medida que amplia seu alcance para além da disciplina da estrutura e do funcionamento da Administração Pública, passando a lidar com a regulação estatal de relações entre particulares, o direito administrativo acumula razões para se submeter à observância de categorias tipicamente constitucionais, como a legitimidade democrática e os limites impostos pelos direitos fundamentais.

O desenvolvimento da regulação social, em sentido amplo, é tributário de uma gradual sofisticação do conceito de poder de polícia da Administração. Fenômeno moderno, seu desenvolvimento acompanha o incremento na complexidade das próprias relações sociais. Assim, não fosse o advento dos automóveis e das rodovias, normas de trânsito hoje absolutamente comezinhas, indispensáveis à organização do tráfego de veículos e à segurança de passageiros, motoristas e pedestres, seriam condenadas como arbitrárias e desarrazoadas. Diretrizes de zoneamento urbano, ao imporem restrições ao uso e à ocupação do solo em determinadas áreas, seriam tidas como arbitrárias intervenções na propriedade se não constituíssem verdadeiras exigências do crescimento populacional e da concentração das pessoas em aglomerados urbanos, sob pena de termos cidades incapazes de fornecer mínimos padrões de qualidade de vida e bem-estar aos seus habitantes.

$\mathrm{O}$ advento das agências reguladoras setoriais - "autarquias especiais que desempenham funções administrativas, normativas e decisórias, dentro de um espaço de 
competências que lhes é atribuído por lei"7 - representa inegável aperfeiçoamento da arquitetura institucional do Estado de direito contemporâneo no sentido do oferecimento de uma resposta da Administração Pública para fazer frente à complexidade das relações sociais verificadas na modernidade. A exigência de agilidade e flexibilidade cada vez maiores do Estado diante das ininterruptas demandas econômicas e sociais que lhe são direcionadas levou à emergência de estruturas administrativas relativamente autônomas e independentes - as chamadas agências - dotadas de mecanismos aptos e eficazes para a regulação de setores específicos, o que inclui a competência para editar atos qualificados como normativos. Na lição de Luís Roberto Barroso, as competências das agências reguladoras podem ser classificadas em executivas - implementação de políticas públicas e diretrizes do legislador -, decisórias - resolução, no âmbito administrativo, dos conflitos entre agentes econômicos do setor e entre estes e os consumidores - e normativas de largo alcance. Consoante, ainda, o magistério de Alexandre Santos de Aragão: "A necessidade de descentralização normativa, principalmente de natureza técnica, é a razão de ser das entidades reguladoras independentes, ao que podemos acrescer o fato de a competência normativa, abstrata ou concreta, integrar o próprio conceito de regulação" ${ }^{8}$

O Estado regulador, assim chamado em oposição tanto ao modelo de Estado absenteísta quanto ao modelo de Estado produtor de bens e serviços, não só estabelece as regras necessárias ao adequado funcionamento de setores econômica e socialmente relevantes, como fiscaliza o seu cumprimento, mediante o exercício do poder de polícia.

Nesse quadro, não se pode deixar de considerar que "a ação disciplinadora dos entes reguladores tornar-se-ia inócua e restariam frustradas as razões de sua instituição, se tais órgãos se restringissem à prática de atos repressivos, por exemplo, sem poder elaborar normas de caráter geral", uma vez que "as agências reguladoras precisam dispor de meios de atuação, de poderes compatíveis com as funções que lhes foram outorgadas". 9

O escopo do modelo regulatório adotado no Brasil não se reduz - a criação da ANVISA o evidencia - à regulação concorrencial, não se limita

7 BARROSO, Luís Roberto. Temas de direito constitucional - volume III. Rio de Janeiro: Renovar, 2008.

8 ARAGÃO, Alexandre Santos de. Agências reguladoras e a evolução do direito administrativo econômico. Rio de Janeiro: Forense, 2002.

9 CUÉLLAR, Leila. As agências reguladoras e seu poder normativo. São Paulo: Dialética, 2001. 
à correção das chamadas "falhas de mercado", incorporando também instrumentos necessários para o atingimento de objetivos gerais de interesse público: regulação social, e não apenas econômica.

Por outro lado, também não se resume ao modelo clássico da regulação de serviços públicos (utility regulation) que inspirou a criação de agências reguladoras setoriais concomitantemente ao processo, iniciado nos anos 1990, de desestatização da exploração de atividades econômicas titularizadas pelo Estado, como telefonia e energia elétrica.

Nesses casos, a atividade regulatória incide sobre o que os administrativistas chamam de relação de sujeição especial, na qual, mediante a celebração de um contrato de concessão, o administrado assente formalmente com um grau mais intenso de ingerência do Estado, que é o titular da atividade que ele pretende explorar. Nessa modalidade de vínculo administrativo, o contrato de concessão emerge como justo título a autorizar menor rigidez na incidência do princípio da legalidade estrita, legitimando, consequentemente, a maior discricionariedade da Administração na elaboração das regras de regência da relação jurídica.

Diferentemente, as funções regulatórias desempenhadas pela ANVISA destinam-se, em grande medida, à disciplina de atividades exercidas em caráter eminentemente privado, não titularizadas pelo Estado, malgrado sua relevância do ponto de vista do interesse público. Não adstrita à regulação concorrencial, tampouco à regulação de serviços públicos, sobressaem, na vocação dessa agência, senão inteiramente, pelo menos com preponderância, os contornos de típico exercício do poder de polícia da Administração, no caso, a sanitária. ${ }^{10}$

O poder de polícia da Administração, no entanto, manifesta-se tanto pela prática de atos específicos de efeitos concretos quanto pela edição de atos normativos abstratos e de alcance generalizado. ${ }^{11}$ Não se mostra estranha ao poder geral de polícia da Administração, portanto, a competência das agências reguladoras para editar atos normativos visando à organização e à fiscalização das atividades por elas reguladas. ${ }^{12}$ Expressa o poder de polícia, todavia, um poder-dever de agir nos limites da lei. No desempenho de função tipicamente

10 SILVA, Clarissa Sampaio. Legalidade e regulação. Belo Horizonte: Fórum, 2005.

11 MELLO, Celso Antônio Bandeira de. Apontamentos sobre o poder de polícia. Revista de Direito Público, n. 9.

12 ARAGÃO, Alexandre Santos de; SAMPAIO, Patrícia R. P. Omissão no exercício do poder normativo das agências e a concorrência desleal. In: ARAGÃO, Alexandre Santos de (Coord.). O poder normativo das agências reguladoras. Rio de Janeiro: Forense, 2011. 
de polícia, conforma-se a atuação da Administração à imposição de "restrições e condicionamentos legalmente instituídos sobre o exercício das liberdades e dos direitos fundamentais, com a finalidade de possibilitar uma convivência harmoniosa e produtiva em termos de segurança, salubridade, decoro e estética". ${ }^{13}$ No exercício da função de polícia, em seu sentido tradicional, "a Administração figura no vínculo jurídico como autoridade pública, utilizando-se de seu poder de império, de sua supremacia perante todos os cidadãos, enquanto exercente de uma função pública, voltada a curar os interesses da coletividade". ${ }^{14}$ Ao contrário da regulação de relações de sujeição especial, não existe, no caso da regulação de relações jurídicas de sujeição geral, justo título autorizando o abandono da legalidade estrita.

Nessa linha de raciocínio, quando incidente sobre atividade titularizada pela iniciativa privada, o poder normativo da Administração não terá a mesma extensão que o exercido na regulação da exploração por particular de uma atividade ou bem titularizados pelo próprio Estado. Ainda que pairem, sobre a atividade econômica desempenhada em regime privado, motivos de interesse público justificadores da intervenção, "não poderá o Poder Público impor regulação que faça com que as autorizações operativas típicas desta modalidade regulatória equivalham a verdadeiras concessões, a uma publicatio, ou seja, não pode o Poder autorizante ter poderes correspondentes aos que existiriam se a atividade fosse um serviço público, sob pena de incidir em fraude à Constituição" ${ }^{15}$

\subsubsection{Regulação e regulamentação: distinções necessárias}

É certo que não se confunde a função normativa das agências reguladoras com a função tradicionalmente exercida pela Administração de regulamentar as leis de modo a viabilizar o seu cumprimento (art. 84, IV, da Lei Maior), e nem com a figura do regulamento autônomo (arts. 84, VI, 103-B, $\$ 4^{0}$, I, e 237 da $\mathbf{C F}$ ). A respeito das aproximações e distanciamentos entre regulação e regulamentação, anota Marcos Juruena Villela Souto:

13 MOREIRA NETO, Diogo de Figueiredo. A administração indireta e sua eficiência. In: MARTINS FILHO, Ives Gandra da Silva; MEYER-PFLUNG, Samantha Ribeiro (Coord.). A intervenção do Estado no domínio econômico: condições e limites. São Paulo: LTr, 2011.

14 OLIVEIRA, José Roberto Pimenta. A ANEEL e serviços de energia elétrica. In: SUNDFELD, Carlos Ari. São Paulo: Malheiros, 2000.

15 ARAGÃO, Alexandre Santos de. Agências reguladoras e a evolução do direito administrativo econômico. Rio de Janeiro: Forense, 2002. 
Ainda que os limites e condições impostos à edição de "regulamentos autônomos" se apliquem integralmente às normas regulatórias, não há que se confundir ambas as espécies de atos normativos; o regulamento, autônomo ou não, é emanado de autoridade política, sem compromisso de neutralidade; a norma regulatória, [...], traça conceitos técnicos, despidos de valoração política (que deve estar contida na norma a ser implementada); deve ser equidistante dos interesses em jogo, resultando de uma ponderação entre os custos e os benefícios envolvidos (daí deve ser necessariamente motivada e editada, preferencialmente, por agente “independente", i.e. protegido contra pressões políticas). ${ }^{16}$ [destaquei]

Apesar de não identificadas aos regulamentos de que tratam os arts. 84, IV e VI, 103-B, §4ํ, I, e 237 da Constituição da República (o que não impede parte da doutrina de sublinhar a existência de pontos de contato entre os institutos), tampouco são vocacionadas, as normas editadas pelas agências no exercício da atividade regulatória, a traduzir espécies normativas primárias. ${ }^{17}$ A liberdade de ação - ou discricionariedade normativa - das agências reguladoras encontra limites nos objetivos fixados na lei e nas políticas públicas estabelecidas pela Administração central. ${ }^{18}$

Os atos normativos das agências reguladoras [...], dando executoriedade às políticas públicas escolhidas, expressas em leis finalísticas, especificarão os direitos e obrigações impostas por lei aos particulares. Note-se que a estatuição primária, autônoma, continua sendo da lei que dita diretrizes/objetivos/princípios. [...] Os atos normativos de direito regulatório deverão pautar-se pelas finalidades estabelecidas na lei de instituição da referida agência, e deverão atender requisitos formais - respeito a normas do processo de criação - e materiais atendimento de finalidade específica e proporcionalidade. ${ }^{19}$

16 SOUTO, Marcos Juruena Villela. Direito administrativo regulatório. Rio de Janeiro: Lumen Juris, 2002.

17 CARDOSO, Henrique Ribeiro. Controle da legitimidade da atividade normativa das agências reguladoras. Rio de Janeiro: Editora Lumen Juris, 2010.

18 ARAGÃO, Alexandre Santos de. Agências reguladoras e a evolução do direito administrativo econômico. Rio de Janeiro: Forense, 2002.

19 CARDOSO, Henrique Ribeiro. Controle da legitimidade da atividade normativa das agências reguladoras. Rio de Janeiro: Editora Lumen Juris, 2010. 


\subsubsection{O princípio da legalidade na regulação setorial}

A função normativa das agências reguladoras, notadamente quando atinge direitos e deveres dos administrados ligados ao Estado tão somente por vínculo de sujeição geral, subordina-se necessariamente ao direito posto, à lei, que deverá "definir as metas principais a serem perseguidas, os princípios a serem observados, os limites de atuação, os contornos das atividades das Agências Reguladoras, as finalidades a que foram instituídas, conceituando-lhes sua margem de atuação" ${ }^{\prime 20}$ Não é por outra razão que, embora dotadas de considerável autonomia, ${ }^{21}$ a medida da competência normativa em que são investidas as agências reguladoras será aquela perfeitamente especificada nas leis - atos do Parlamento - pelas quais são criadas. ${ }^{22}$ Colho, nessa linha, consistentes lições doutrinárias. Gustavo Binembojm aborda com propriedade o status jurídico das agências reguladoras diante da primazia do princípio da legalidade:

O princípio da legalidade serve tanto à autonomia pública dos cidadãos (democracia) como a sua autonomia privada (liberdade). Por seu intermédio, os cidadãos podem se tornar autores das suas próprias normas de direito (autonomia pública) e defender a sua vida particular de indevidas interferências externas (autonomia privada). Em uma palavra, por meio do império da lei, os cidadãos se tornam senhores do seu destino coletivo (democracia) e individual (liberdade). Esta, a dimensão substantiva do princípio da legalidade.

A legalidade administrativa se presta não apenas a proteger a liberdade dos indivíduos (CF, art. 5ㅇ, II) como para limitar a atuação da autoridade administrativa ( $\mathrm{CF}$, art. 37, caput). A dupla alusão ao princípio da legalidade na Carta de 1988 - no art. 5ㅜㅡ, II, e no art. 37, caput - não é, portanto, ociosa. É que, enquanto para os particulares legalidade significa poder fazer tudo que a lei não proíbe (art. 5o, II), para a Administração Pública legalidade significa só poder fazer o que a lei prescreve. A lei serve, assim, de limite e condição para o legítimo

20 EFING, Antônio Carlos (Coord.). Agências reguladoras e a proteção do consumidor brasileiro. Curitiba: Juruá, 2009.

21 JUSTEN FILHO, Marçal. Curso de direito administrativo. São Paulo: Saraiva, 2005.

22 MOTTA, Paulo Roberto Ferreira. Agências reguladoras. São Paulo: Manole, 2003. 
exercício da atividade administrativa. Por isso se costuma dizer que, em Direito Administrativo, a legalidade se apresenta como uma vinculação positiva à lei: a norma legal cumpre o duplo papel de servir de fundamento de validade para a ação do administrador e, ao mesmo tempo, o de traçar os limites da sua atuação.

A circunstância de as agências reguladoras gozarem de um acentuado grau de autonomia não tem o condão de subverter a clássica hierarquia existente entre atos legislativos e atos administrativos. Em última análise, todo e qualquer ato emanado de órgão ou entidades da Administração Pública está sujeito ao princípio da legalidade, inscrito no art. 37, caput, da Constituição da República. ${ }^{23}$

Para Benedicto Porto Neto, na mesma linha,

[...] a pura e simples delegação de competência normativa para a Administração não é comportada pelo ordenamento jurídico. A lei não pode simplesmente autorizar que a Administração Pública exerça a função normativa. Seria verdadeiro despropósito admitir que a Constituição repartisse as funções do Estado (função legislativa, executiva e jurisdicional) para permitir que, posteriormente, o legislador as reunisse num ou noutro ente.

Não é possível admitir que o princípio da legalidade, uma garantia constitucional, seja esvaziado por ato do próprio legislador.

[...] no entanto, esta circunstância é muito diferente daquela em que o legislador define, na própria lei, alguns standards (parâmetros) que devam ser observados pela Administração Pública na expedição de normas gerais e abstratas.

É legítima a outorga de competência normativa para a Administração quando a própria lei fixe estes parâmetros de forma clara e completa, fazendo com que ela exerça essa competência em conformidade com a vontade do legislador (ou da lei). Ou seja, devem estar contidos na própria lei os princípios, os limites da atuação da Agência no

23 BINENBOJM, Gustavo. Agências reguladoras independentes e democracia no Brasil. In: BINENBOJM, Gustavo (Coord.). Agências reguladoras e democracia. Rio de Janeiro: Editora Lumen Juris, 2006. 
exercício da competência normativa e as finalidades que devem, por meio delas, ser alcançadas. ${ }^{24}$

Arnoldo Wald e Luiza Rangel de Moraes chamam atenção para o fato de que, na previsão de competência normativa a entes reguladores, "há de ser preservado o Estado de Direito, evitando atribuições que ostentem caráter absoluto, situação de sujeição indefinida de determinadas pessoas aos poderes públicos, distorcendo, assim, a regra geral de que as restrições às liberdades constituem uma exceção ao sistema de direitos e garantias constitucionais". ${ }^{25}$

José Adércio Leite Sampaio, discorrendo sobre os limites materiais dos regulamentos editados pelo Poder Executivo de um modo geral, fornece considerações pertinentes ao devido dimensionamento do âmbito da produção normativa das agências reguladoras em particular:

Ficam de fora de sua atribuição normativa, portanto, as modificações de disposições normativas primárias ou, simplesmente, a criação no ordenamento jurídico de direitos ou de obrigações jurídicas destinadas a vincular fora dos círculos da própria Administração. Não pode, assim, facultar o que a lei proíbe, nem ordenar o que a lei não obriga; tampouco limitar, modificar ou ampliar direitos, deveres, ações ou exceções, tornar exemplificativo o que é taxativo ou suspender ou adiar a execução da lei, instituir tribunais ou criar autoridades públicas, nem tampouco estabelecer formas de exteriorização de um ato diferentes daquelas determinadas pela lei. ${ }^{26}$ [destaquei]

Na mesma linha, pontifica Celso Antônio Bandeira de Mello:

[...] o princípio da legalidade, além de assentar-se na própria estrutura do Estado de Direito e, pois, do Sistema constitucional como um todo, está radicado especificamente nos arts. $5^{\circ}$, II, 37, caput, e 84, IV, CF. Estes dispositivos atribuem ao princípio em causa uma compostura muito estrita e rigorosa, não deixando válvula para que

24 NETO, Benedicto Porto. A Agência Nacional de Telecomunicações. In: SUNDFELD, Carlos Ari (Coord.). Direito administrativo econômico. São Paulo: Malheiros, 2002.

25 WALD, Arnoldo; MORAES, Luiza Rangel de. Agências reguladoras. Revista de Informação Legislativa, Brasília, a. 36, n. 141, jan./mar. 1999.

26 SAMPAIO, José Adércio Leite. A Constituição reinventada pela jurisdição constitucional. Belo Horizonte: Del Rey, 2002. 
o Executivo se evada de seus grilhões. É, aliás, o que convém a um país de tão acentuada tradição autocrática, despótica, na qual o Poder Executivo, abertamente ou através de expedientes [...] viola de modo sistemático direitos e liberdades públicas e tripudia à vontade sobre a repartição de poderes [...]. Logo, a Administração não poderá proibir ou impor comportamento algum a terceiro, salvo se estiver previamente embasada em determinada lei que lhe faculte proibir ou impor algo a quem quer que seja. Vale dizer, não lhe é possível expedir regulamento, instrução, regulação, portaria ou seja lá que ato for para coartar a liberdade dos administrados, salvo se em lei já existir delineada a contenção ou imposição que o ato administrado venha a minudenciar. ${ }^{27}$ [destaquei]

A seu turno, observa Samantha Ribeiro Meyer-Pflung:

O poder normativo do Poder Executivo consiste em regulamentar os ditames legais. O regulamento tem uma relação intrínseca com a lei em razão de seu caráter genérico (no sentido material), mas se diferencia dela na exata medida em que carece do caráter inovador das leis, ou seja, ele não tem a capacidade de inaugurar a ordem jurídica.

[...]

As agências reguladoras desfrutam de poder normativo, mas essa faculdade não pode ser confundida com a figura do decreto autônomo, pois seus atos devem ter base legal.

$[\ldots]$

Não há como negar que as agências reguladoras têm poder normativo precipuamente para editar normas de caráter técnico, específico, relativos à sua área de atuação. Trata-se de um poder normativo técnico e de caráter complementar. Isso decorre do fato de o legislador não ter condições de descer às minúcias e especificidades técnicas de determinados setores econômicos [...]. Tendo em vista justamente a complexidade que envolve esses setores é que se faz necessária a presença de agências reguladoras que normatizem essas questões técnicas e específicas, com efeitos erga omnes.

BANDEIRA DE MELLO, Celso Antônio. Curso de direito administrativo. 29. ed. São Paulo: Malheiros, 2012. 
[...]

O poder normativo das agências decorre das próprias leis que as instituem, portanto, está-se diante de uma delegação que não é incondicionada, uma vez que há parâmetros estabelecidos nos ditames legais. ${ }^{28}$ [destaquei]

\subsubsection{Limites materiais do poder normativo}

Embora apto a produzir atos normativos abstratos com força de lei, o poder normativo exercido pelas agências reguladoras vê os seus limites materiais condicionados aos parâmetros fixados pelo legislador. Assim,

em tese, todo regramento editado por agências ou outro órgão autônomo não pode ir além do previsto em lei, não cabendo qualquer tipo de delegação legislativa ou de deslegalização em sentido próprio. A atribuição do poder regulador, seja em sede constitucional, seja legal, diz respeito a questões de natureza técnica, restrita e pontual, podendo ser desafiada por uma contestação judicial das medidas ou disciplinas adotadas em face das disposições legais pertinentes e do fundamento técnico apresentado. ${ }^{29}$ [destaquei]

A norma regulatória preserva a sua legitimidade quando cumpre o conteúdo material da legislação setorial. Nesse exercício, pode, sim, conter regras novas, desde que preservada a ordem vigente de direitos e obrigações, que se impõe como limite ao agir administrativo: regras novas, e não direito novo. Consoante observa, com clareza, Marçal Justen Filho,

O princípio da legalidade significa a ausência de poder normativo da agência para instituir norma jurídica que não tenha sido, anteriormente, delineada legislativamente. Comojá destacado, a instituição de uma norma faz-se pela previsão de uma hipótese de incidência a

28 MEYER-PFLUNG, Samantha Ribeiro. As agências reguladoras no Brasil e seu poder normativo. In: MARTINS FILHO, Ives Gandra da Silva; MEYER-PFLUNG, Samantha Ribeiro (Coord.). A intervenção do Estado no domínio econômico: condições e limites. São Paulo: LTr, 2011.

29 SAMPAIO, José Adércio Leite. A Constituição reinventada pela jurisdição constitucional. Belo Horizonte: Del Rey, 2002. 
que se vincula um mandamento. $O$ princípio da legalidade impõe que uma lei tenha previsto alguns aspectos da hipótese e o núcleo do mandamento normativo. Caberá à agência complementar essa espécie de espaço normativo em branco, que se verifica a propósito da norma editada legislativamente.

Haveria usurpação de competência legislativa se a agência resolvesse criar uma hipótese de incidência e um mandamento normativo, sem que tal já estivesse previamente instituído em lei. É inconstitucional delegação de competência legislativa em que a lei atribua à agência o poder de criar hipóteses de incidência e mandamentos normativos.

$[\ldots]$

Os dados fundamentais da hipótese de incidência e do mandamento normativo apenas podem ser veiculados por meio de lei. Não se admite que a lei estabeleça um padrão abstrato, preenchível pelos mais variados conteúdos, e remeta à agência seu desenvolvimento autônomo. ${ }^{30}$ [destaquei]

Tal entendimento doutrinário converge com a orientação afirmada pelo Plenário desta Casa. Ao apreciar a medida cautelar requerida na ADI 1668/DF (Relator Ministro Marco Aurélio, DJ 16.4.2004), ajuizada em face de diversos dispositivos da Lei no 9.472/1997, a Lei Geral de Telecomunicações (LGT), e pela qual instituída a Agência Nacional de Telecomunicações ANATEL, o Supremo Tribunal Federal teve a oportunidade de se debruçar sobre questões análogas às ora apresentadas, em particular ao deferir em parte os pedidos de liminar, (i) quanto ao art. 19, IV e X, para, sem redução de texto, dar-lhes interpretação conforme a Constituição Federal, com o objetivo de fixar exegese segundo a qual a competência da Agência Nacional de Telecomunicações - ANATEL para expedir normas subordina-se aos preceitos legais e regulamentares que regem a outorga, prestação e fruição dos serviços públicos de telecomunicações no regime público e no regime privado; e, (ii) quanto ao art. 22, II, para, também sem redução de texto, dar-lhe interpretação conforme a Constituição para fixar a exegese segundo a qual a competência do Conselho Diretor fica submetida às normas gerais e específicas de licitação e contratação previstas nas respectivas leis de regência, vencido o Ministro Moreira Alves, que os indeferia.

30 FILHO, Marçal Justen. O direito das agências reguladoras independentes. São Paulo: Dialética, 2002. 
Os citados incisos IV e $\mathbf{X}$ do art. 19 da LGT enunciam a competência da ANATEL para "expedir normas quanto à outorga, prestação e fruição dos serviços de telecomunicações no regime público" (IV) e "expedir normas sobre prestação de serviços de telecomunicações no regime privado" (X). Já o art. 22, II, fixa a competência do Conselho Diretor da Agência para "aprovar normas próprias de licitação e contratação".

Na assentada, aderiu o Ministro Relator, em relação ao art. 19, IV e X, da Lei n⿳0 9.472/1997, à posição inaugurada pelo Ministro Sepúlveda Pertence, nos seguintes termos:

Peço vênia ao eminente Relator, com relação aos incisos IV e X, para propor interpretação conforme. Estou de acordo com S. Exa., em que nada impede que a Agência tenha funções normativas, desde, porém, que absolutamente subordinadas à legislação, e, eventualmente, às normas de segundo grau, de caráter regulamentar, que o Presidente da República entenda baixar.

Assim, de acordo com o início do voto de S. Exa., entendo que nada pode subtrair da responsabilidade do agente político, que é o Chefe do Poder Executivo, a ampla competência reguladora da lei das telecomunicações.

Dou interpretação conforme para enfatizar que os incisos IV e X referem-se a normas subordinadas à lei e, se for o caso, aos regulamentos do Poder Executivo. [destaquei]

Reajustado nessa parte, o voto do eminente Relator, Ministro Marco Aurélio, registra:

Relativamente aos incisos IV e X, empresto a eles interpretação conforme à Carta da República, ou seja, a atuação da Agência há de fazer-se de acordo com as normas de âmbito legal e regulamentar de regência. [destaquei]

Vale ressaltar, ainda, que o eminente Ministro Moreira Alves não aderiu à proposta de interpretação conforme a Constituição, ficando, portanto, vencido no aspecto, não porque entendesse compatível com a Constituição republicana interpretação diversa, que eventualmente atribuísse maiores amplitude e autonomia à competência normativa da agência reguladora, e 
sim porque, a seu ver, "não há necessidade de interpretação conforme a Constituição para se dizer o óbvio".

Ao emprestar ao art. 22, II, da Lei Geral de Telecomunicações, interpretação consentânea com a Carta Política, sem redução do seu texto, consignou o Relator:

A competência ora atribuída ao Conselho Diretor não há de resultar no afastamento das normas gerais e específicas de licitação previstas nas leis de regência. Deve ficar restrita ao atendimento de peculiaridades inerentes aos serviços, sem prejuízo, portanto, do sistema de licitação, tal como existente na ordem jurídica em vigor. [destaquei]

Pertinente, ainda, a transcrição de excerto do voto convergente do Ministro Sepúlveda Pertence:

Sr. Presidente, pode parecer uma interpretação óbvia, como outras que temos dado. $\mathrm{O}$ dispositivo fala numa experiência nova de Agência reguladora independente ou paraindependente ou, pelo menos de regime especial; fala em normas próprias que podem tanto ser de especificação do sistema legal em relação ao seu objeto próprio telecomunicações e todo esse mundo de serviços postos sob a disciplina dessa Agência -, mas, também, normas que excepcionem no sistema legal. Julgo prudente dizer que é no primeiro sentido que se podem expedir essas normas sub-regulamentares. [destaquei]

Mais recentemente, ao apreciar o recurso ordinário em mandado de segurança no 28.487, no qual discutido se a Câmara de Regulação do Mercado

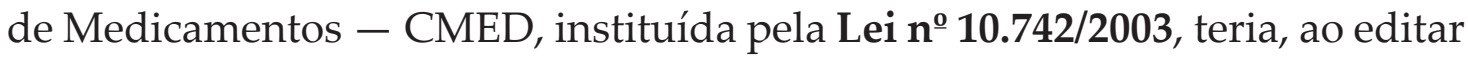
a Resolução no 4/2006, exorbitado da sua competência legal para exercer a regulação econômica do mercado farmacêutico, a $1^{1}$ Turma desta Corte, em julgamento realizado em 26.02.2013 (DJe 14.3.2013), à unanimidade, concluiu, ao exame do ato normativo concreto, ter sido exercida a função reguladora da Administração Pública em consonância com as diretrizes e os limites previstos na lei. Não deixou de salientar o voto proferido pelo eminente Relator, Dias Toffoli, todavia, a necessidade de estrita observância a tais limites como condição de legitimidade dos atos normativos praticados no exercício da função reguladora: 
[...] O poder regulamentar outorgado ao Poder Executivo está limitado ao conteúdo da lei, competindo-lhe editar normas para orientar a relação entre o Poder Público e o administrado. A atuação administrativa com esse fundamento, portanto, é legítima quando está restrita a expedir normas complementares à ordem jurídico-formal vigente; em outras palavras, quando configura exercício de função típica do Poder Executivo, qual seja, a execução das leis. [...]. [MS 28.487/DF, Relator Ministro Dias Toffoli, 1를 Turma, DJe 14.3.2013]

Finalmente, ao julgar improcedente a ADI 4954/AC (Relator Ministro Marco Aurélio julgamento em 20.8.2014, DJe 30.10.2014), proposta contra leis estaduais disciplinando o comércio de artigos de conveniência em farmácias e drogarias, o Plenário do Supremo Tribunal Federal manifestou-se, incidentalmente, a respeito dos limites da competência normatizadora da Agência Nacional de Vigilância Sanitária, presente a Resolução da Diretoria Colegiada (RDC) no 173/2003 da ANVISA, que pretendia vedar a venda, em farmácias e drogarias, de "produtos alheios aos conceitos de medicamento, cosmético, produto para saúde e acessórios, alimento para fins especiais, alimento com delegação de propriedade funcional e alimento com alegação de propriedades de saúde". In verbis:

PROCESSO OBJETIVO - INCONSTITUCIONALIDADE - CRIVO DO SUPREMO - [...]. CONTROLE CONCENTRADO DE CONSTITUCIONALIDADE - OBJETO. O controle concentrado de constitucionalidade é feito a partir do cotejo do pronunciamento atacado com o Diploma Maior, mostrando-se desinfluente o fato de haver norma diversa, de índole federal, a tratar de certo tema - precedente: Ação Direta de Inconstitucionalidade $\mathrm{n}^{\mathrm{o}} 3.645 / \mathrm{PR}$, Pleno, relatora ministra Ellen Gracie. AGÊNCIA REGULADORA - PRINCÍPIO DA LEGALIDADE. As agências reguladoras estão submetidas, como órgãos administrativos, ao princípio da legalidade. COMPETÊNCIA NORMATIVA - COMÉRCIO - FARMÁCIAS - ARTIGOS DE CONVENIÊNCIA. Constitucional é a lei de estado-membro que verse o comércio varejista de artigos de conveniência em farmácias e drogarias. [ADI 4954/AC, Relator Ministro Marco Aurélio, Tribunal Pleno, julgamento em 29.10.2014, DJe 30.10.2014, destaquei] 
Destaco excerto do voto do eminente Relator:

[...] Quanto ao argumento da proibição por meio da Resolução RDC no 328, de 1999, com a redação dada pela Resolução RDC no 173 , de 2003, da Agência Nacional de Vigilância Sanitária, verifica-se inovação infralegal na ordem jurídica que não pode ser oposta ao exercício legislativo dos estados, sob pena de afronta ao princípio da legalidade. A circunstância de a Lei federal $n^{0}$ 9.782, de 1999, mediante a qual foi criada a aludida Agência, ter instituído amplo espaço de atuação regulatória em favor da autarquia não a torna titular de atribuição tipicamente legislativa $[\ldots]$.

$\mathrm{O}$ aspecto foi expressamente enfrentado, sob o mesmo enfoque, na ADI 4949/RJ (Relator Ministro Ricardo Lewandowski, Tribunal Pleno, julgamento em 11.9.2014, DJe 03.10.2014) e na ADI 4951/PI[...] (Relator Ministro Teori Zavascki, julgamento em 24.9.2014, DJe 26.11.2014), da qual peço vênia para extrair fragmento:

A Lei federal 9.782/99, que criou a Agência Nacional de Vigilância Sanitária, tampouco institui qualquer espécie de proibição semelhante. Apenas autorizou a respectiva autarquia a "regulamentar, controlar e fiscalizar produtos e serviços que envolvam risco à saúde pública" (art. $8^{\circ}$ ), dentre eles "medicamentos de uso humano, suas substâncias ativas e demais insumos, processos e tecnologias", mas desde que respeitada a legislação em vigor. [destaquei]

Ainda em igual sentido, a ADI 4.093/SP, de minha relatoria (julgamento em 24.9.2014, DJe 30.10.2014):

AÇÃO DIRETA DE INCONSTITUCIONALIDADE PROPOSTA PELO GOVERNADOR DO ESTADO DE SÃO PAULO. LEI ESTADUAL № 12.623/2007. DISCIPLINA DO COMÉRICIO DE ARTIGOS DE CONVENIÊNCIA EM FARMÁCIAS E DROGARIAS. USURPAÇÃO DA COMPETÊNCIA DA UNIÃO. IMPROCEDÊNCIA. A Lei Federal 5.991/73, ao dispor sobre o controle sanitário do comércio de drogas, medicamentos, insumos farmacêuticos e correlatos, destinou a farmácias e drogarias a exclusividade na comercialização de tais produtos sem proibir, contudo, a oferta de artigos de conveniência. [...] Às agências 
reguladoras não compete legislar, e sim promover a normatização dos setores cuja regulação lhes foi legalmente incumbida. A norma regulatória deve se compatibilizar com a ordem legal, integrar a espécie normativa primária, adaptando e especificando o seu conteúdo, e não substituí-la ao inovar na criação de direitos e obrigações. Em espaço que se revela qualitativamente diferente daquele em que exercida a competência legiferante, a competência regulatória é, no entanto, conformada pela ordem constitucional e legal vigente. As normas da ANVISA que extrapolem sua competência normativa - como é o caso da proibição de comércio de artigos de conveniência em farmácias e drogarias - não se revelam aptas a obstar a atividade legiferante dos entes federados. Ação direta de inconstitucionalidade julgada improcedente. [ADI 4093, Relatora Ministra Rosa Weber, Tribunal Pleno, julgamento em 24.9.2014, DJe 17.10.2014, destaquei]

Sem se afastar do entendimento afirmado nos precedentes, conquanto razoável admitir que o princípio da reserva de lei inscrito no art. 50, II, da CF permita a delegação de funções normativas - e não legislativas - a entes de feição administrativa, não se pode dispensar a lei formalizadora da delegação de preestabelecer as diretrizes de tais competências mediante tipificação mínima do conteúdo normativo a ser integrado pela Administração. Dessa forma, pode-se afirmar que "delegações demasiado amplas não são compatíveis com referido princípio constitucional, por não oferecerem critérios para avaliar se a norma de competência foi ou não cumprida pela Administração". ${ }^{31}$

Mutatis mutandis, revela-se elucidativo o paralelo com a figura do tipo em branco, em que lei formal, ao prever determinada sanção, incumbe ao Poder Executivo a especificação das hipóteses sobre as quais tem ela incidência, notadamente a partir de critérios técnicos.

É o que fazem, v.g., o art. 1oㅜ parágrafo único, da Lei $\mathbf{n}^{\mathbf{0}} \mathbf{1 1 . 3 4 3 / 2 0 0 6}$, ao atribuir expressamente ao Poder Executivo da União a tarefa de relacionar em listas atualizadas periodicamente as substâncias ou produtos capazes de causar dependência, e assim considerados como drogas, na forma do caput, e os arts. 189 e 190 da CLT, ao delinearem os contornos das atividades ou operações consideradas insalubres - "aquelas que, por sua natureza, condições

31 BRUNA, Sérgio Varella. Agências reguladoras: poder normativo, consulta pública, revisão judicial. São Paulo: Editora Revista dos Tribunais, 2003. 
ou métodos de trabalho, exponham os empregados a agentes nocivos à saúde, acima dos limites de tolerância fixados em razão da natureza e da intensidade do agente e do tempo de exposição aos seus efeitos" - , remetendo ao Ministério do Trabalho, em seguida, a elaboração do quadro de atividades e operações insalubres e a adoção de normas sobre critérios de caracterização de insalubridade, limites de tolerância a agentes agressivos, meios de proteção e tempo máximo de exposição do empregado a esses agentes.

Em absoluto se admite, todavia, a delegação pura e simples à Administração, a criação ad nutum de uma figura infracional, por portaria ou resolução, com a imposição da correspondente sanção.

Não bastasse o disposto nos arts. 5\%, II, e 37, caput, o núcleo essencial do direito de livre-iniciativa, inscrito no art. 170, parágrafo único, da $\mathbf{C F}$, assegura que somente a lei pode restringir o livre exercício de qualquer atividade econômica, e o art. 174 da Carta Política é expresso ao subordinar a atividade regulatória do Estado, seja no papel de agente normativo, seja no desempenho das funções de fiscalização e planejamento, à forma da lei, isto é, à legalidade estrita. Transcrevo-os:

Art. 170. A ordem econômica, fundada na valorização do trabalho humano e na livre-iniciativa, tem por fim assegurar a todos existência digna, conforme os ditames da justiça social, observados os seguintes princípios:

$[\ldots]$

Parágrafo único. É assegurado a todos o livre exercício de qualquer atividade econômica, independentemente de autorização de órgãos públicos, salvo nos casos previstos em lei.

Art. 174. Como agente normativo e regulador da atividade econômica, o Estado exercerá, na forma da lei, as funções de fiscalização, incentivo e planejamento, sendo este determinante para o setor público e indicativo para o setor privado.

Embora não caiba às agências legislar, lhes compete, sim, promover a normatização dos setores cuja regulação lhes foi legalmente incumbida. ${ }^{32}$

32 CARDOSO, Henrique Ribeiro. Controle da legitimidade da atividade normativa das agências reguladoras. Rio de Janeiro: Editora Lumen Juris, 2010. 
Poder normativo, repito à exaustão, não é poder legislativo: a abertura ou indeterminação dos conceitos empregados nos textos normativos não pode ser interpretada como atribuição ilimitada de competências discricionárias, sob pena de elevar o agente regulador à condição de superego da sociedade. Nessa esteira, a advertência da doutrina: "Para evitar o déficit democrático destas instituições devemos ter sempre clara a sua vinculação às pautas estabelecidas pelo Legislador para as políticas públicas cuja implementação lhes é atribuída, assim como a necessária coordenação que devem possuir com o restante da Administração Pública". ${ }^{33}$

O campo no qual o agente regulador atua com liberdade tem suas margens definidas pelos conteúdos que podem ser extraídos, senão da letra da lei, pelo menos do propósito manifesto do legislador. Mostra-se legítima a atuação normativa do agente regulador sempre que capaz de ser justificada como a integração de uma evidente escolha legislativa. Em outras palavras, a orientação seguida pelo Administrador deve necessariamente traduzir uma escolha previamente realizada pelo Legislador, que lhe confere autoridade.

O Legislador, de fato, não pode delegar a responsabilidade pela decisão política, mas a escolha dos meios para a persecução da política por ele definida pode ser objeto de delegação.

Isso em absoluto significa reduzir a regulação setorial ao preenchimento de lacunas e muito menos à execução mecânica da lei. Dotada de inquestionáveis relevância e responsabilidade, a função regulatória só é dignificada pelo reconhecimento de que não é inferior nem exterior à legislação. Exercese, isto sim, em um espaço que se revela qualitativamente diferente, pelo seu viés técnico, ainda que conformada pela ordem constitucional e legal vigentes.

O poder normativo atribuído às agências reguladoras pelas respectivas leis instituidoras consiste em instrumento para que dele lance mão o agente regulador de um determinado setor econômico ou social para a implementação das diretrizes, finalidades, objetivos e princípios expressos na Constituição e na legislação setorial. No domínio da regulação setorial, a edição de ato normativo geral e abstrato (poder normativo) destina-se à especificação de direitos e obrigações dos particulares, sem que possa, a agência reguladora, criá-los ou extingui-los. O poder normativo atribuído às agências reguladoras

33 ARAGÃO, Alexandre Santos de. Agências reguladoras e a evolução do direito administrativo econômico. Rio de Janeiro: Forense, 2002. 
vocaciona-se, como bem pontua Sérgio Guerra, a "traduzir, por critérios técnicos, os comandos previstos na Carta Magna e na legislação infraconstitucional acerca do subsistema regulado". ${ }^{34}$

Com efeito, a norma regulatória deve compatibilizar-se com a ordem legal, integrar a espécie normativa primária, adaptando e especificando o seu conteúdo, e não substituí-la ao inovar na criação de direitos e obrigações. Seu domínio próprio é o do preenchimento, à luz de critérios técnicos, dos espaços normativos deixados em aberto pela legislação, não o da criação de novos espaços. Hierarquicamente subordinado à lei, o poder normativo atribuído às agências reguladoras não lhes faculta inovar $a b$ ovo na ordem jurídica, mormente para "impor restrições à liberdade, igualdade e propriedade ou determinar alteração do Estado das pessoas". ${ }^{35}$

As agências reguladoras deverão escolher tecnologias e estratégias de ação eficientes, com a ressalva de que não sigam interesses ou preferências próprias - apenas finalidades coletivas estabelecidas em lei devem ser perseguidas. ${ }^{36}$

Vale ressaltar, ainda, que, sendo uma das justificativas centrais para a emergência da regulação setorial por agências independentes o elevado grau de segurança jurídica exigido pela complexidade das relações sociais no mundo contemporâneo, admitir alto grau de discricionariedade do agente regulador ou baixa vinculação da regulação aos limites impostos pela lei contraria a sua própria finalidade institucional, passando as agências reguladoras de agentes estabilizadores a fatores de instabilidade jurídico-institucional.

É o que observa Maria Sylvia Zanella Di Pietro, para quem o chamado poder normativo das agências reguladoras consiste na

possibilidade [...[, do mesmo modo que sempre se reconheceu a inúmeros órgãos e entidades administrativas no direito brasileiro (como o Conselho Monetário Nacional, o Banco Central, o Conselho Nacional de

34 GUERRA, Sérgio. Introdução ao direito das agências reguladoras. Rio de Janeiro: Freitas Bastos, 2004.

35 CUÉLLAR, Leila. As agências reguladoras e seu poder normativo. São Paulo: Dialética, 2001.

36 CARDOSO, Henrique Ribeiro. Controle da legitimidade da atividade normativa das agências reguladoras. Rio de Janeiro: Editora Lumen Juris, 2010. 
Educação e tantos outros) de, por meio de atos normativos, interpretar ou explicitar conceitos indeterminados, especialmente de natureza técnica, contidos em leis e regulamentos. Trata-se de conceitos que se inserem na ideia de especialização das agências, exigindo definição mais precisa, porém sem inovar na ordem jurídica.

O que as agências não podem fazer, porque falta o indispensável fundamento constitucional, é baixar regras de conduta, unilateralmente, inovando na ordem jurídica, afetando direitos individuais, substituindo-se ao legislador. Esse óbice constitui-se no mínimo indispensável para preservar o princípio da legalidade e o princípio da segurança jurídica. Principalmente, não podem as agências baixar normas que afetem os direitos individuais, impondo deveres, obrigações, penalidades, ou mesmo outorgando benefícios, sem previsão em lei. Trata-se de matéria de reserva de lei, consoante decorre do artigo 5o, inciso II, da Constituição. Não se pode deixar de lembrar que a proteção dos direitos individuais frente ao Estado constituiu a própria razão de ser da construção do princípio da legalidade, sem o qual não existe Estado de Direito. ${ }^{37}$

Na mesma linha, Conrado Hubner Mendes ensina que "as agências reguladoras, pelo simples fato de serem agências reguladoras, não podem, por sua própria natureza, realizar atividades que outras autarquias não possam. Cada uma, mais uma vez, possui seu balizamento segundo dois diplomas básicos: a Constituição Federal e sua lei de criação". ${ }^{38}$

\subsubsection{As competências previstas nos incisos III e XV do art. 79 da Lei n? 9.782/1999}

Nesse ponto, cumpre descortinar as possibilidades semânticas dos preceitos de lei impugnados (incisos III e XV do art. $7^{\circ}$ da Lei $\mathbf{n}^{\mathbf{0}}$ 9.782/1999), em face das balizas hermenêuticas impostas pela Constituição da República.

37 DI PIETRO, Maria Sylvia Zanella. Limites da função reguladora das agências diante do princípio da legalidade. In: DI PIETRO, Maria Sylvia Zanella (Org.). Direito regulatório: temas polêmicos. Belo Horizonte: Fórum, 2009.

38 MENDES, Conrado Hubner. A nova regulação estatal e as agências independentes. In: SUNDFELD, Carlos Ari (Coord.). Direito administrativo econômico. São Paulo: Malheiros, 2002. 


\subsubsection{Art. 79 , XV, da Lei n? 9.782/1999}

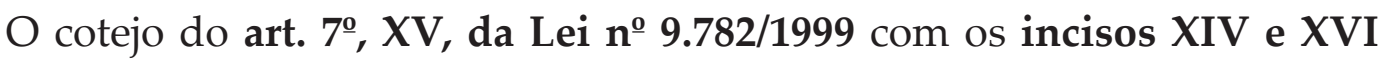
do mesmo dispositivo contribui para clarificar a natureza e a dimensão da competência da ANVISA nele prevista:

Art. $7^{\circ}$ Compete à Agência proceder à implementação e à execução do disposto nos incisos II a VII do art. $2^{\circ}$ desta Lei, devendo:

$[\ldots]$

XIV - interditar, como medida de vigilância sanitária, os locais de fabricação, controle, importação, armazenamento, distribuição e venda de produtos e de prestação de serviços relativos à saúde, em caso de violação da legislação pertinente ou de risco iminente à saúde;

XV - proibir a fabricação, a importação, o armazenamento, a distribuição e a comercialização de produtos e insumos, em caso de violação da legislação pertinente ou de risco iminente à saúde;

XVI - cancelar a autorização de funcionamento e a autorização especial de funcionamento de empresas, em caso de violação da legislação pertinente ou de risco iminente à saúde;

Os incisos transcritos possuem a mesma estrutura textual. Em todos eles é atribuída à agência uma competência executiva específica - interditar, proibir, cancelar - a ser exercida conforme a hipótese de incidência que definem: "em caso de violação da legislação pertinente ou de risco iminente à saúde".

Da leitura dos incisos XIV, XV e XVI do art. $7^{\mathbf{o}}$ da Lei $\mathbf{n}^{\mathbf{0}}$ 9.782/1999, emerge, assim, que a competência da ANVISA para interditar, proibir ou cancelar as atividades neles indicadas comporta duas hipóteses de exercício.

A primeira delas é a violação da legislação pertinente. No caso do inciso $\mathrm{XV}$, objeto da presente impugnação, se o poder de proibir está condicionado à prévia aferição de ofensa ao direito pertinente, não há falar contemple a hipótese competência para edição de normas primárias. A competência, aqui, é essencialmente executiva, e não constitutiva do direito: reprimir a atividade realizada em desconformidade com a legislação vigente.

A segunda hipótese em que pode ser exercida a competência da ANVISA para proibir a fabricação, a comercialização e a importação de produtos e insumos, nos termos do preceito em exame, é a constatação de risco iminente 
à saúde. O adjetivo "iminente" evidencia que o dispositivo confere à ANVISA a necessária competência para o exercício do poder geral de cautela administrativa como dimensão do poder de polícia: tomar medidas repressivas concretas para suspender ou evitar risco iminente à saúde. É o que a Agência faz, por exemplo, quando suspende a circulação de um lote de medicamentos com defeito de fabricação à evidência de risco iminente à saúde da população. Riscos ordinariamente associados aos produtos submetidos ao controle e fiscalização da ANVISA, na medida em que inerentes ao seu uso regular, não têm o condão de atrair a incidência da hipótese normativa descrita pela expressão "risco iminente à saúde", o que só pode ser caracterizado como risco extraordinário, localizado, concreto e determinado.

Como se vê, o sentido do art. 7º, XV, da Lei $\mathrm{n}^{\mathrm{o}}$ 9.782/1999 se reveste de univocidade e em absoluto desafia a supremacia da Constituição - até mesmo porque não encerra atribuição alguma de competência normativa para a proibição de produtos ou insumos em caráter geral e primário.

Não gravado o art. 7º XV, da Lei no 9.782/1999 com o distintivo traço da polissemia, inviável lançar mão da técnica da interpretação conforme a Constituição, à ausência do seu pressuposto metodológico - o caráter polissêmico do preceito impugnado.

Julgo improcedente, por conseguinte, o pedido de interpretação conforme a Constituição do art. 7º , XV, parte final, da Lei no 9.782/1999.

\subsubsection{Art. 79, III, da Lei n’ 9.782/1999}

Passo ao exame do pedido de interpretação conforme a Constituição do art. 7º, III, da Lei no 9.782/1999, que, diversamente, atribui à ANVISA competência para "estabelecer normas, propor, acompanhar e executar as políticas, as diretrizes e as ações de vigilância sanitária".

Se, de um lado, o preceito afirma a competência da ANVISA para estabelecer normas - como não poderia deixar de ser em se tratando de ente regulador - , de outro, afirma que, no tocante às políticas e às diretrizes de vigilância sanitária - conceitos que, estes sim, permitem efetiva modificação da ordem jurídica - , a competência da Agência se circunscreve a propor, acompanhar e executar. O inciso III do art. $7^{\text {o }}$ da Lei $\mathrm{n}^{\mathrm{o}}$ 9.782/1999, dessa forma, reafirma o art. 7º, caput, no que exclui da ANVISA a competência, reservada à União, de definir a política nacional de vigilância sanitária (art. 2ํㅡ, I, da Lei no 9.782/1999). 
Ora, ao dimensionar a competência da ANVISA, o art. $\mathbf{7}^{\mathbf{0}}$, caput, da Lei no 9.782/1999 lhe outorga a implementação e a execução, no âmbito do Sistema Nacional de Vigilância Sanitária, das competências da União especificamente enumeradas nos incisos II a VII do art. 2\%. Exclui categoricamente das atribuições da ANVISA, portanto, a competência da União fixada no art. $\mathbf{2}^{\mathbf{0}}$, I, para "definir a política nacional de vigilância sanitária".

Relativamente à definição da política nacional de vigilância sanitária, compete à Diretoria Colegiada da ANVISA apenas "propor ao Ministro de Estado da Saúde as políticas e diretrizes governamentais destinadas a permitir à Agência o cumprimento de seus objetivos" (art. 15, II, da Lei no 9.782/1999), sendo, a efetiva formulação da política nacional do setor, atribuição da União a ser exercida pelo Ministério da Saúde (art. 2º I e $\$ 1^{\circ}$, I, da Lei $n^{0}$ 9.782/1999), resguardada, logicamente, a competência do Poder Legislativo.

A ANVISA implementa a política nacional de vigilância sanitária, cuja formulação, no entanto, não lhe compete. A competência normativa conferida à ANVISA pelo art. $7^{\circ}$, III, da Lei $n^{0}$ 9.782/1999 não contempla a definição da pauta política relativamente às medidas para o controle do tabaco, condicionada a atuação do ente regulador, na matéria, à observância da agenda estabelecida pelo legislador, por expressa disposição do art. $8^{\circ}$, caput, $\S 1^{\circ}, \mathrm{X}$, desse diploma:

Art. $8^{\circ}$ Incumbe à Agência, respeitada a legislação em vigor regulamentar, controlar e fiscalizar os produtos e serviços que envolvam risco à saúde pública.

$\S 1^{\circ}$ Consideram-se bens e produtos submetidos ao controle e fiscalização sanitária pela Agência:

$[\ldots]$

$\mathrm{X}$ - cigarros, cigarrilhas, charutos e qualquer outro produto fumígero (sic), derivado ou não do tabaco;

Nessa ordem de ideias, reconheço que o dissenso interpretativo evidenciado entre a autora da ação direta e a ANVISA - destinatária das normas impugnadas - a respeito da extensão dos poderes normativos a ela conferidos pelo art. $7^{\circ}$, III, da Lei n⿳0 9.782/1999, em particular quanto à regulação da produção, da importação e da comercialização de produtos fumígenos derivados do tabaco, indica que não desprovida de razão a corrente majoritária formada no precedente citado (medida cautelar na ADI 1.668/DF) 
quanto ao emprego da técnica da interpretação conforme a Constituição em caso como este. Não obstante, comungo da compreensão então manifestada pelo eminente Ministro Moreira Alves no sentido de que supérfluo lançar mão da técnica da interpretação conforme a Constituição para afirmar que a competência normativa da ANVISA subordina-se à observância da legislação vigente.

Anoto, por oportuno, que, segundo o compreendo, o art. 7º, III, da Lei n⿳0 9.782/1999 em absoluto obstrui o pleno exercício da função regulatória da ANVISA, não só no tocante ao controle, no marco legal vigente, dos produtos fumígenos, derivados ou não do tabaco, como a indispensável normatização dos demais setores a ela submetidos, tais como medicamentos, alimentos, cosméticos, equipamentos médicos, agrotóxicos, resíduos etc. Não há falar, pois, em limbo jurídico.

Assim, à luz dos fundamentos apresentados, julgo improcedente o pedido de interpretação conforme a Constituição do art. $\mathbf{7}^{\mathbf{0}}$, III, da Lei no 9.782/1999 e passo ao exame do pedido sucessivo.

\section{Pedido sucessivo}

Cinge-se o pedido sucessivo à declaração de inconstitucionalidade da Resolução da Diretoria Colegiada (RDC) no 14/2012 da Agência Nacional de Vigilância Sanitária - ANVISA, em caráter autônomo, "por violação direta à Constituição da República".

\subsection{Conhecimento}

O equacionamento desse pedido supõe um juízo sobre a conformação, ou não, do seu conteúdo material aos limites fixados na Constituição da República para o exercício legítimo pela ANVISA da sua competência normativa. Em outras palavras, cabe definir, nesta sede, o fundamento material de validade da proibição, veiculada na RDC no 14/2012, da fabricação, da importação e da comercialização, no país, de produtos fumígenos derivados do tabaco que contenham as substâncias ou compostos que define como aditivos.

Reconheço a cognoscibilidade do pedido de declaração de inconstitucionalidade deduzido na ação direta contra a Resolução da Diretoria Colegiada $n^{\mathbf{0}}$ 14/2012 da ANVISA, por se tratar de ato normativo que, destinado 
a expressar imperatividade e coerção estatais, reúne as características da abstração, da generalidade e da autonomia. É, por isso, perfeitamente impugnável pela via processual objetiva eleita, nos termos dos arts. 102, I, a, e 103, $\S^{\circledR}{ }^{\circ}$, da Constituição da República e 3ํㅡ, I, da Lei no 9.868/1999, e na esteira de reiterados precedentes desta Casa.

Com efeito, a jurisprudência do Supremo Tribunal Federal orienta-se no sentido de não admitir a instauração do procedimento jurisdicional de fiscalização in abstracto de constitucionalidade quando carecedor, o ato normativo objeto da impugnação, de coeficiente de normatividade suficientemente apto a qualificá-lo como ato normativo de caráter primário ou autônomo.

Nessa linha, firme o entendimento de que eventual vício de inconstitucionalidade que resulte, materialmente, da lei que confere suporte jurídico ao ato normativo infralegal questionado expõe não este, mas somente aquela, se for o caso, à tutela jurisdicional objetiva. É que, em tal hipótese, "eventual conflito hierárquico-normativo com a Constituição, se houver, resultará, pois, de vícios a serem identificados no próprio ato legislativo. Só por repercussão vale dizer, por via indireta, reflexa ou oblíqua - é que se poderá vislumbrar, no regulamento em questão, possível eiva de inconstitucionalidade. Esta, contudo, acaso configurada, certamente não resultará, originariamente, do próprio ato regulamentar" (ADI 996/DF, Relator Ministro Celso de Mello, DJ 06.5.1994).

Disso decorre que o desrespeito à lei, apenas, não fundamenta, senão indiretamente, como desdobramento ulterior, juízo de inconstitucionalidade sobre ato normativo a ela hierarquicamente subordinado, situando-se a controvérsia jurídica, nessa hipótese, no campo da legalidade/ilegalidade, e sendo certo que "a inconstitucionalidade que autoriza o exercício do controle concentrado é apenas aquela decorrente da incompatibilidade frontal e direta com o Texto Maior" (ADI 996/DF, Relator Ministro Celso de Mello, DJ 06.5.1994).

Nessas condições, "evidente o descabimento da ação direta quando a pretendida inconstitucionalidade do ato regulamentar, que é meramente ancilar e secundário, representa uma derivação e um efeito consequencial de eventual ilegitimidade constitucional da própria lei em sua condição jurídica de ato normativo primário e principal" (ADI 996/DF, Relator Ministro Celso de Mello, DJ 06.5.1994).

No entanto, ainda que para rechaçar a admissibilidade de ação direta de inconstitucionalidade ajuizada contra atos normativos secundários - atos que regulamentam normas primárias, notadamente as leis formais - , não tem deixado a jurisprudência desta Casa de afirmar a viabilidade do controle abstrato da constitucionalidade de ato normativo de natureza regulamentar 
quando, não precedido diretamente por lei, manifesta conteúdo jurídico-normativo em certa medida primário. É o que se extrai da ementa do acórdão proferido ao exame da ADI 2.792-AgR/MG, relatada pelo Ministro Carlos Velloso (DJ 12.3.2004):

EMENTA: CONSTITUCIONAL. ADMINISTRATIVO. REGULAMENTO. NOTÁRIOS. CONTROLE CONCENTRADO DE CONSTITUCIONALIDADE: IMPOSSIBILIDADE. Resolução no 350/99 e Editais 001/99 e 002/99 do Tribunal de Justiça do Estado de Minas Gerais. I. - Ato regulamentar não está sujeito ao controle de constitucionalidade, dado que se vai ele além do conteúdo da lei, pratica ilegalidade e não inconstitucionalidade. Somente na hipótese de não existir lei que preceda o ato regulamentar, é que poderia este ser acoimado de inconstitucional, assim sujeito ao controle de constitucionalidade. Precedentes do Supremo Tribunal Federal. II. - No caso, têm-se atos regulamentares da Lei 12.919/98, do Estado de Minas Gerais. III. Agravo regimental não provido. [ADI 2.792-AgR/MG, Relator Ministro Carlos Velloso, DJ 12.3.2004, destaquei]

Na mesma linha, destaco ainda os seguintes precedentes desta Corte:

EMENTAS: 1. AÇÃO DIRETA DE INCONSTITUCIONALIDADE. Impugnação de resolução do Poder Executivo estadual. Disciplina do horário de funcionamento de estabelecimentos comerciais, consumo e assuntos análogos. Ato normativo autônomo. Conteúdo de lei ordinária em sentido material. Admissibilidade do pedido de controle abstrato. Precedentes. Pode ser objeto de ação direta de inconstitucionalidade, o ato normativo subalterno cujo conteúdo seja de lei ordinária em sentido material e, como tal, goze de autonomia nomológica. 2. INCONSTITUCIONALIDADE. Ação direta. Resolução nº 12.000-001, do Secretário de Segurança do Estado do Piauí. Disciplina do horário de funcionamento de estabelecimentos comerciais, consumo e assuntos análogos. Inadmissibilidade. Aparência de ofensa aos arts. 30, I, e 24, V e VI, da CF. Usurpação de competências legislativas do Município e da União. Liminar concedida com efeito ex nunc. Aparenta inconstitucionalidade a resolução de autoridade estadual que, sob pretexto do exercício do poder de polícia, discipline horário de 
funcionamento de estabelecimentos comerciais, matéria de consumo e assuntos análogos. [ADI 3.731-MC/PI, Relator Ministro Cezar Peluso, DJ 29.8.2007, destaquei]

AÇÃO DIRETA DE INCONSTITUCIONALIDADE. LEI № 1.798/97; E ART. 8음 DO DECRETO № 9.115/98, DO ESTADO DO MATO GROSSO DO SUL. ALEGADA CONTRARIEDADE AOS ARTS. 150, $\S 6^{\circ}$; E 155, §2º , XII, G, DA CONSTITUIÇÃO FEDERAL. O primeiro ato normativo estadual, instituindo benefícios relativos ao ICMS sem a prévia e necessária celebração de convênio entre os Estados e o Distrito Federal, contraria os dispositivos constitucionais sob enfoque. Alegação de inconstitucionalidade igualmente plausível no tocante ao art. $8^{\circ}$ do Decreto $\mathrm{n}^{\circ}$ 9.115/98, que, extrapolando a regulamentação da mencionada lei, fixa, de forma autônoma, incentivos fiscais sem observância das mencionadas normas da Carta da República. Ação julgada procedente, para declarar a inconstitucionalidade das normas em questão. [ADI 2.439/MS, Relator Ministro Ilmar Galvão, DJ 13.11.2002, destaquei]

EMENTA: Ação direta de inconstitucionalidade. Medida Liminar. Resolução 04/00, de 13 de junho de 2000, do Órgão Especial do Tribunal de Justiça do Estado de Santa Catarina que altera a jornada de trabalho dos servidores do Tribunal e da Justiça de primeiro grau do Estado. Não há dúvida de que a Resolução em causa, que altera o horário de expediente da Secretaria do Tribunal de Justiça e da Justiça de primeiro grau do Estado de Santa Catarina, e que consequentemente reduz para seis horas, em turno único, a jornada de trabalho de todos os servidores de ambas, é ato normativo e tem caráter autônomo, porquanto dá como fundamento, para justificar a competência para tanto do Órgão Especial do Tribunal de Justiça, o disposto nos artigos 96, I, "a" e " $\mathrm{b}$ ", da Constituição Federal e no artigo 83, III, da Constituição Estadual. Em exame sumário como é o compatível com pedido de concessão de liminar, é inegável a plausibilidade jurídica da arguição de inconstitucionalidade em causa, com base especialmente na alegação de ofensa aos artigos 5, II, 37, "caput" (ambos relativos ao princípio da legalidade), 96, I, "a" e "b" (que versa a competência dos Tribunais) e 61, §1을 II, "c" (que atribui competência exclusiva ao Chefe do 
Poder Executivo para a iniciativa de lei relativa a regime jurídico do servidor público), todos da Constituição Federal. - Por outro lado, é conveniente a suspensão da eficácia da Resolução em apreço, não só pela relevância da arguição de inconstitucionalidade dela, mas também por causa do interesse do público em geral e, em particular, dos serviços administrativos do Tribunal e da justiça de primeiro grau com a não redução da jornada de trabalho de todos os seus servidores. Liminar deferida para suspender, ex nunc e até o julgamento final desta ação, a eficácia da Resolução n⿳o 04/00, de 13 de junho de 2000, do Órgão Especial do Tribunal de Justiça do Estado de Santa Catarina. [ADI 2.308MC/DF, Relator Ministro Moreira Alves, DJ 05.10.2001, destaquei]

EMENTA: Ação direta de inconstitucionalidade. Dispositivos dos Provimentos $n^{\text {os }}$ 08/95-CGJ, 34/95-CGJ e 39/95-CGJ da Corregedoria-Geral da Justiça do Tribunal de Justiça do Estado do Rio Grande do Sul. Pedido de liminar. - Esta Corte já firmou o entendimento de que só é cabível ação direta de inconstitucionalidade para verificar-se se há ofensa ao princípio constitucional da reserva legal ou de invasão de competência legislativa de um dos membros da Federação, quando o ato normativo impugnado é autônomo, ou seja, ato normativo que não vise a regulamentar lei ou que não se baseie nela, pois, caso contrário, a questão se situa primariamente no âmbito legal, não dando ensejo ao conhecimento da ação direta de inconstitucionalidade. Ação de que não se conhece, ficando prejudicado o pedido de liminar. [ADI 1.383-MC/RS, Relator Ministro Moreira Alves, DJ 18.10.1996, destaquei]

Esta Corte Suprema também já decidiu converter em ação direta de inconstitucionalidade (ADI 4.105, Relator Ministro Marco Aurélio, DJe 17.6.2010) arguição de descumprimento de preceito fundamental proposta em face de Portaria do Ministério da Saúde, à convicção de traduzir, o ato normativo impugnado, ato normativo abstrato e autônomo.

No julgamento da medida liminar requerida na ação direta de inconstitucionalidade $\mathrm{n}^{\mathrm{o}}$ 2.075/RJ, o Plenário do Supremo Tribunal Federal, à unanimidade, rejeitou a preliminar de não conhecimento do feito e deferiu a suspensão cautelar do Decreto nº 25.168/1999 do Estado do Rio de Janeiro, que pretendia fixar o teto remuneratório dos servidores públicos estaduais, em decisão assim ementada: 
AÇÃO DIRETA DE INCONSTITUCIONALIDADE - REMUNERAÇÃO, SUBSÍDIOS, PENSÕES E PROVENTOS DOS SERVIDORES PÚBLICOS, ATIVOS E INATIVOS, DO ESTADO DO RIO DE JANEIRO - FIXAÇÃO DE TETO REMUNERATÓRIO MEDIANTE ATO DO PODER EXECUTIVO LOCAL (DECRETO ESTADUAL № 25.168/99) - INADMISSIBILIDADE - POSTULADO CONSTITUCIONAL DA RESERVA DE LEI EM SENTIDO FORMAL ESTIPULAÇÃO DE TETO REMUNERATÓRIO QUE TAMBÉM IMPORTOU EM DECESSO PECUNIÁRIO - OFENSA À GARANTIA CONSTITUCIONAL DA IRREDUTIBILIDADE DO ESTIPÊNDIO FUNCIONAL (CF, ART. 37, XV) - MEDIDA CAUTELAR DEFERIDA. REMUNERAÇÃO DOS AGENTES PÚBLICOS E POSTULADO DA RESERVA LEGAL. - O tema concernente à disciplina jurídica da remuneração funcional submete-se ao postulado constitucional da reserva absoluta de lei, vedando-se, em consequência, a intervenção de outros atos estatais revestidos de menor positividade jurídica, emanados de fontes normativas que se revelem estranhas, quanto à sua origem institucional, ao âmbito de atuação do Poder Legislativo, notadamente quando se tratar de imposições restritivas ou de fixação de limitações quantitativas ao estipêndio devido aos agentes públicos em geral. - $O$ princípio constitucional da reserva de lei formal traduz limitação ao exercício das atividades administrativas e jurisdicionais do Estado. A reserva de lei - analisada sob tal perspectiva - constitui postulado revestido de função excludente, de caráter negativo, pois veda, nas matérias a ela sujeitas, quaisquer intervenções normativas, a título primário, de órgãos estatais não legislativos. Essa cláusula constitucional, por sua vez, projeta-se em uma dimensão positiva, eis que a sua incidência reforça o princípio, que, fundado na autoridade da Constituição, impõe, à administração e à jurisdição, a necessária submissão aos comandos estatais emanados, exclusivamente, do legislador. Não cabe, ao Poder Executivo, em tema regido pelo postulado da reserva de lei, atuar na anômala (e inconstitucional) condição de legislador, para, em assim agindo, proceder à imposição de seus próprios critérios, afastando, desse modo, os fatores que, no âmbito de nosso sistema constitucional, só podem ser legitimamente definidos pelo Parlamento. É que, se tal fosse possível, o Poder Executivo passaria a desempenhar atribuição que lhe é institucionalmente 
estranha (a de legislador), usurpando, desse modo, no contexto de um sistema de poderes essencialmente limitados, competência que não lhe pertence, com evidente transgressão ao princípio constitucional da separação de poderes. [...]. [ADI 2075-MC/RJ, Relator Ministro Celso de Mello, DJ 27.6.2003, destaquei]

Na ocasião, ao rejeitar a preliminar de não conhecimento da ação direta, manejada que foi contra ato normativo infralegal - decreto do Chefe do Poder Executivo estadual - , arguida pelo Governador do Estado do Rio de Janeiro, assentou o eminente relator:

Entendo, [...], que o ato normativo ora impugnado - que não se vincula a qualquer diploma legislativo, editado que foi para regulamentar, desde logo, autonomamente, o novo regime remuneratório instituído pela EC 19/98, [...] qualifica-se, para fins de controle abstrato de constitucionalidade, [...], como espécie inteiramente revestida de conteúdo normativo.

$[\ldots]$

Esse conteúdo material do ato em questão claramente evidencia que o decreto impugnado encerra uma proposição de dever-ser e veicula, em seu âmbito, enquanto manifestação subordinante de vontade, uma prescrição - revestida de inquestionável positividade [...], subsumindo-se, desse modo, no plano dogmático, à noção conceitual de norma.

$[\ldots]$

Vê-se, desse modo, que o ato ora em exame, ao dar expressão formal a uma atividade nitidamente veiculadora de restrições jurídicas, tornou possível realizar, na dimensão do seu alcance, um dos momentos concretizadores do processo normativo, muito embora o procedimento institucional concernente à edição desse ato estatal tenha sido efetivado de maneira incompatível com a ortodoxia dos padrões que regem, de modo estrito, dentro da organização constitucional brasileira, o sistema de poderes limitados.

Como o ato estatal ora impugnado possui inegável densidade normativa, revela-se, por isso mesmo, suscetível de apreciação em sede de controle abstrato de constitucionalidade. [destaquei] 
Na sessão realizada em 25 de maio de 2006, o Plenário referendou a medida liminar concedida pelo Ministro Celso de Mello (AC 1033-AgR-QO) para suspender a eficácia da Instrução Normativa nº 01/2005 da Secretaria do Tesouro Nacional, que pretendia impor sanção a Estado-membro (ente político) em razão de inscrição, no Cadastro Único de Convênio (CAUC), por inadimplemento obrigacional, de ente da Administração estadual indireta (autarquia, empresa pública, entidade paraestatal) e, portanto, dotado de personalidade jurídica própria. Eis a ementa:

A RESERVA DE LEI EM SENTIDO FORMAL QUALIFICA-SE COMO INSTRUMENTO CONSTITUCIONAL DE PRESERVAÇÃO DA INTEGRIDADE DE DIREITOS E GARANTIAS FUNDAMENTAIS. $O$ princípio da reserva de lei atua como expressiva limitação constitucional ao poder do Estado, cuja competência regulamentar, por tal razão, não se reveste de suficiente idoneidade jurídica que lhe permita restringir direitos ou criar obrigações. Nenhum ato regulamentar pode criar obrigações ou restringir direitos, sob pena de incidir em domínio constitucionalmente reservado ao âmbito de atuação material da lei em sentido formal. - $\mathrm{O}$ abuso de poder regulamentar, especialmente nos casos em que o Estado atua "contra legem" ou "praeter legem", não só expõe o ato transgressor ao controle jurisdicional, mas viabiliza, até mesmo, tal a gravidade desse comportamento governamental, o exercício, pelo Congresso Nacional, da competência extraordinária que lhe confere o art. 49, inciso V, da Constituição da República e que lhe permite "sustar os atos normativos do Poder Executivo que exorbitem do poder regulamentar [...]". Doutrina. Precedentes (RE 318.873-AgR/SC, Rel. Min. CELSO DE MELLO, v.g.). Plausibilidade jurídica da impugnação à validade constitucional da Instrução Normativa STN no 01/2005. [AC 1033-AgRQO, Relator Ministro Celso de Mello, Tribunal Pleno, DJ 16.6.2006, destaquei]

Em manifestação doutrinária sobre o tema, o Ministro Gilmar Mendes expõe, com eloquência, as razões que norteiam a admissibilidade da ação direta em tais hipóteses:

Estou também convencido de que a clara violação de autorizações legislativas por parte do Poder Executivo, especialmente quando 
impõe obrigações, não se traduz apenas no descumprimento da lei. Na verdade, fere a própria Constituição, de forma elementar, a ideia de reserva legal. Então não há como dizer que aqui estamos diante de uma questão tipicamente de legalidade.

$[\ldots]$

Acho que se colocam essas duas hipóteses, tanto do Regulamento delegado, aquele que tem um marco institucional definido, o conteúdo vem inicialmente definido no texto da lei, mas, a discrição do órgão regulador é ampla, e há casos em que o enunciado da competência é tão abstrato que nós estamos diante, efetivamente, de casos de regulamento autônomo.

Como as agências reguladoras detêm competências ligadas ao seu perfil institucional, não vejo como não se admitir o controle de constitucionalidade abstrato de seus atos em ação direta de inconstitucionalidade. ${ }^{39}$

Entendo que não poderia ser diferente. Um Estado que transfere a entes administrativos, como é o caso das chamadas agências reguladoras, parte da tarefa de elaboração normativa não pode prescindir de mecanismos institucionais de fiscalização, em face da Constituição da República, da legitimidade formal e material dessa produção normativa extraparlamentar, sob pena de se admitir uma situação paradoxal: as normas gerais e abstratas emanadas do Congresso Nacional ficam sujeitas ao controle de constitucionalidade ao mesmo tempo que normas de mesma densidade, igualmente marcadas pelos traços de generalidade e abstração, porém emanadas das mais diversas estruturas burocráticas que não contam com a mesma legitimação democrática proporcionada pelo voto popular, pairam acima dos limites impostos pela Carta da República ao Poder Legislativo.

Dotada a Resolução da Diretoria Colegiada da ANVISA no 14/2012 de conteúdo normativo suficientemente primário, uma vez inexistente no ordenamento jurídico pátrio ato normativo de grau hierárquico superior contemplando expressamente a proibição da utilização de aditivos em produtos fumígenos derivados do tabaco (o que adiante será retomado e aprofundado),

39 MENDES, Gilmar Ferreira. Controle de constitucionalidade dos atos administrativos das agências reguladoras. In: ANAIS DO SEMINÁRIO AS AGÊNCIAS REGULADORAS. Escola da Magistratura Federal da 1ª Região, 2004. 
resulta inviável reduzir a controvérsia, na espécie, a mero conflito de legalidade, sem estatura constitucional. Qualifica-se o ato normativo impugnado, ainda, pelos predicados de autonomia, abstração, generalidade e imperatividade, os quais lhe imprimem densidade normativa suficiente a credenciá-lo à tutela de constitucionalidade in abstracto.

Conheço, pois, do pedido sucessivo esgrimido, em caráter autônomo, contra a Resolução da Diretoria Colegiada (RDC) da ANVISA no 14/2012.

\subsection{Mérito}

Ato contínuo, há que definir, para o completo equacionamento da demanda, se, ao proibir a importação e a comercialização no país de produtos fumígenos derivados do tabaco que contenham as substâncias ou compostos que define como aditivos, a Resolução da Diretoria Colegiada da ANVISA nº 14/2012 foi ou não, à luz da Constituição e da legislação em vigor, legitimamente introduzida por órgão dotado dos poderes necessários para fazer irromper, plena de validade e eficácia, a sua existência na ordem jurídica pátria.

\subsubsection{A cláusula constitucional do direito à saúde}

A interpretação da Lei no 9.782/1999 não pode deixar de render homenagem à cláusula constitucional do direito à saúde.

Não há dúvida de que a Constituição, tomada como sistema, autoriza o Estado a impor limitações aos direitos fundamentais, em face da necessidade de conformá-lo com outros direitos fundamentais igualmente protegidos. Assim, o direito fundamental à liberdade de iniciativa, consagrado nos arts. 10, IV, e 170, caput, da Lei Maior como fundamento da República Federativa do Brasil e princípio geral da ordem econômica, não impede a imposição, pelo Estado, de condições e limites para a exploração de atividades privadas, tendo em vista a necessidade de sua compatibilização com os demais princípios, garantias, direitos fundamentais e proteções constitucionais, sejam individuais ou sociais, destacando-se, no caso do controle do tabaco, a proteção da saúde e o direito à informação. Essa compreensão encontra ressonância nas palavras do eminente Ministro Cezar Peluso, ao afirmar "de todo compatível com o ordenamento limitar a liberdade de iniciativa a bem de 
outras finalidades jurídicas tão ou mais relevantes, como a defesa da livre concorrência e o exercício da vigilância estatal sobre setor particularmente crítico para a saúde pública" (AC 1.657-MC, DJe 30.8.2007). Na mesma linha, salienta o eminente Ministro Luís Roberto Barroso, em artigo acadêmico, que:

[...] há relativo consenso no sentido de que os direitos não são absolutos. Não se admite, nessa linha, o exercício ilimitado das prerrogativas que cada direito pode facultar, principalmente quando se cuide de direitos veiculados sob a forma de normas-princípios.

$[\ldots]$

Seria absurdo admitir [...] que o exercício de um direito pudesse chegar a ponto de inviabilizar a vida em sociedade ou de violar direitos de terceiros. Daí porque se reconhece [...] a possibilidade de restringir o exercício de direitos fundamentais. ${ }^{40}$

O tratamento dado à saúde na Carta Política, cuja promulgação completará em outubro próximo trinta anos, diferencia-se, em relação aos regimes anteriores, porque pela primeira vez ligado à tutela da pessoa humana. ${ }^{41}$ Textualmente relacionado entre os direitos fundamentais sociais, os vetores hermenêuticos do pluralismo (preâmbulo) e da dignidade da pessoa humana (art. $1^{\circ}$, III) desautorizam reduzir o direito à saúde à dimensão meramente prestacional. O caráter ambivalente do direito fundamental à saúde consagrado na Constituição Federal - que apresenta aspectos ao mesmo tempo de direito individual e social, de direito de defesa e de proteção, de direito subjetivo e prestacional - é destacado pela doutrina:

Da natureza de direito subjetivo, tomada como interesse negativo da intangibilidade física passou, também, a interesse positivo, a uma proteção ativa à integridade psicofísica, que abrange o meio ambiente e o local de trabalho. A expansão conceitual da saúde para além do direito público subjetivo, assumindo caráter de oponibilidade erga

40 BARROSO, Luís Roberto. Liberdade de expressão e limitação a direitos fundamentais. Ilegitimidade de restrições à publicidade de refrigerantes e sucos. Revista de Direito Público da Economia - RDPE, Belo Horizonte, a. 2, n. 7, jul./set. 2004.

41 TEIXEIRA, Ana Carolina Brochado. Saúde, corpo e autonomia privada. Rio de Janeiro: Renovar, 2010. 
omnes também é de grande relevância, vez que pode ser oponível não apenas contra o Estado, mas também contra terceiros. Não se trata de dimensões antagônicas, mas complementares..$^{42}$ [destaquei]

Os preceitos constitucionais que elevam a saúde à estatura de direito social (art. $\mathbf{6}^{\mathbf{0}}$ ) de todos, e incumbem ao Estado o dever de garanti-la mediante "políticas sociais e econômicas que visem à redução do risco de doença" (art. 196), impõem a adoção de uma agenda positiva voltada à concretização desse direito.

Ora, os conteúdos desde já decididos pelo Poder Constituinte aquilo que o Poder Constituinte, representante primário do povo soberano, textualmente decidiu retirar da esfera de avaliação e arbítrio do Poder Legislativo, representante secundário do povo soberano - podem ser afirmados, sem necessidade de intermediação política, na medida em que direta e necessariamente extraídos da cláusula constitucional do direito à saúde tomada como princípio.

Com base nisso, já assentou o Supremo Tribunal Federal que o fornecimento de medicamentos e a prestação de assistência à saúde, porquanto materialmente assimiláveis à dimensão prestacional do direito à saúde, integram o dever do Estado de promover e proteger a saúde pública prestações atribuídas ao Estado diretamente pela Constituição. Destaco precedente:

PACIENTE COM HIV/AIDS - PESSOA DESTITUÍDA DE RECURSOS FINANCEIROS - DIREITO À VIDA E À SAÚDE - FORNECIMENTO GRATUITO DE MEDICAMENTOS - DEVER CONSTITUCIONAL DO PODER PÚBLICO (CF, ARTS. 5ㅇ, CAPUT, E 196) - PRECEDENTES (STF) - RECURSO DE AGRAVO IMPROVIDO. O DIREITO À SAÚDE REPRESENTA CONSEQUÊNCIA CONSTITUCIONAL INDISSOCIÁVEL DO DIREITO À VIDA. - O direito público subjetivo à saúde representa prerrogativa jurídica indisponível assegurada à generalidade das pessoas pela própria Constituição da República (art. 196). Traduz bem jurídico constitucionalmente tutelado, por cuja integridade deve velar, de maneira responsável, o Poder Público, a quem incumbe formular - e implementar - políticas sociais e econômicas

42 Idem. 
idôneas que visem a garantir, aos cidadãos, inclusive àqueles portadores do vírus HIV, o acesso universal e igualitário à assistência farmacêutica e médico-hospitalar. - $\mathrm{O}$ direito à saúde - além de qualificar-se como direito fundamental que assiste a todas as pessoas - representa consequência constitucional indissociável do direito à vida. O Poder Público, qualquer que seja a esfera institucional de sua atuação no plano da organização federativa brasileira, não pode mostrar-se indiferente ao problema da saúde da população, sob pena de incidir, ainda que por censurável omissão, em grave comportamento inconstitucional. A INTERPRETAÇÃO DA NORMA PROGRAMÁTICA NÃO PODE TRANSFORMÁ-LA EM PROMESSA CONSTITUCIONAL INCONSEQUENTE. - O caráter programático da regra inscrita no art. 196 da Carta Política - que tem por destinatários todos os entes políticos que compõem, no plano institucional, a organização federativa do Estado brasileiro - não pode converter-se em promessa constitucional inconsequente, sob pena de o Poder Público, fraudando justas expectativas nele depositadas pela coletividade, substituir, de maneira ilegítima, o cumprimento de seu impostergável dever, por um gesto irresponsável de infidelidade governamental ao que determina a própria Lei Fundamental do Estado. DISTRIBUIÇÃO GRATUITA DE MEDICAMENTOS A PESSOAS CARENTES. - O reconhecimento judicial da validade jurídica de programas de distribuição gratuita de medicamentos a pessoas carentes, inclusive àquelas portadoras do vírus HIV/AIDS, dá efetividade a preceitos fundamentais da Constituição da República (arts. 5º, caput, e 196) e representa, na concreção do seu alcance, um gesto reverente e solidário de apreço à vida e à saúde das pessoas, especialmente daquelas que nada têm e nada possuem, a não ser a consciência de sua própria humanidade e de sua essencial dignidade. Precedentes do STF. [RE 271.286-AgR/RS, Relator Ministro Celso de Mello, Segunda Turma, DJ 24.11.2000]

Do arranjo constitucional pode ser inferida, ainda, a legitimidade da Administração para tomar medidas voltadas especialmente à saúde de grupos vulneráveis, como crianças e adolescentes, idosos, povos indígenas e usuários de substâncias causadoras de dependência. Mais do que uma orientação, tais comandos encerram verdadeiro dever de agir positivamente relativamente à regulação dos produtos derivados do tabaco. A proteção da 
saúde, adequadamente considerada como norma principiológica, consiste em proposição objetiva, deontológica e teleológica. Nessa linha, colho a lição doutrinária de Cláudia Lima Marques e Bruno Miragem:

O direito fundamental à saúde implica, assim, por sua própria natureza estabelecida no texto da norma constitucional, tanto em uma prestação do Estado na forma de assistência material (alocação de recursos financeiros no setor e oferecimento de políticas públicas de acesso ao atendimento de saúde - prestação do serviço público de saúde), quanto a iniciativas que visem a redução do risco de doença, o que, neste caso, importa na adoção, por via legal e administrativa, de providências que a própria Constituição ou o conhecimento técnico ao tempo da atuação governamental estabeleça como adequadas à realização do comando constitucional.

$[\ldots]$

Sendo assim, [...] o Estado está obrigado a atuar positivamente na proteção da saúde dos consumidores de produtos nocivos e/ou perigosos, como hoje reconhecemos ser os derivados de tabaco, e somente assim trará harmonia aos direitos fundamentais envolvidos. ${ }^{43}$

É nesse sentido que a nota técnica encaminhada pela Diretoria de Monitoramento e Fiscalização da ANVISA para subsidiar a manifestação da Agência em face da presente ação afirma, como fundamento constitucional de validade da RDC n 14/2012, o "dever-poder de cumprir sua finalidade institucional de promover a proteção da saúde da população, por intermédio do controle sanitário da produção e da comercialização de produtos e serviços submetidos à vigilância sanitária".

É fato que não existem níveis seguros para o consumo dos produtos fumígenos derivados do tabaco - o uso normal, regular e esperado é em si mesmo nocivo à saúde, conforme já assinalado. Cabe, pois, nesse contexto, à Agência, o papel de expressar os contornos técnicos, da configuração normativa pertinente ao controle do tabaco, sendo certo que não representa

43 MARQUES, Cláudia Lima; MIRAGEM, Bruno. A constitucionalidade das restrições à publicidade de tabaco por lei federal: diálogo e adequação do princípio da livre-iniciativa econômica à defesa do consumidor e da saúde pública. In: PASQUALOTTO, Adalberto (Org.). Publicidade de tabaco. São Paulo: Atlas, 2015. 
a RDC no 14/2012 efetiva alteração do regime jurídico, senão a especificação de aspectos técnicos relacionados à composição dos produtos derivados do tabaco.

\subsubsection{Restrições aos produtos derivados do tabaco previstas no ordenamento jurídico brasileiro}

Ao editar a Resolução da Diretoria Colegiada - RDC nำ14/2012, definindo normas e padrões técnicos sobre limites máximos de alcatrão, nicotina e monóxido de carbono nos cigarros e restringindo o uso dos denominados aditivos nos produtos fumígenos derivados do tabaco, a Agência Nacional de Vigilância Sanitária atuou em conformidade com os lindes constitucionais e legais das suas prerrogativas, expressos na observância do marco legal vigente, em estrita observância da competência normativa que lhe outorgam os arts. $7^{\circ}$, III, e $8^{\circ}, \S^{\circ} \stackrel{\circ}{ }, X$, da Lei $n^{\circ}$ 9.782/1999.

Apenas para situar a controvérsia, faz-se oportuna uma breve rememoração das restrições aos produtos derivados do tabaco previstas, em âmbito federal, no ordenamento jurídico brasileiro.

A Lei n⿳o 8.069/1990 - Estatuto da Criança e do Adolescente - proíbe a venda à criança - pessoa de até doze anos de idade incompletos - ou ao adolescente - aquela entre doze e dezoito anos de idade - de "produtos cujos componentes possam causar dependência física ou psíquica ainda que por utilização indevida" (art. 81, III), hipótese normativa que inequivocamente compreende os produtos fumígenos derivados do tabaco. No art. 243 são tipificadas como crimes sujeitos a pena de detenção as seguintes condutas:

Art. 243. Vender, fornecer ainda que gratuitamente, ministrar ou entregar, de qualquer forma, a criança ou adolescente, sem justa causa, produtos cujos componentes possam causar dependência física ou psíquica, ainda que por utilização indevida:

Pena - detenção de 2 (dois) a 4 (quatro) anos, e multa, se o fato não constitui crime mais grave. [destaquei]

Sancionado, na sua redação original, com pena de "detenção de seis meses a dois anos, e multa, se o fato não constitui crime mais grave", o crime previsto no art. 243 do ECA teve a severidade da punição aumentada pelo 
art. $6^{\circ}$ da Lei n⿳ 10.764/2003 para "detenção de dois a quatro anos, e multa, se o fato não constitui crime mais grave". Índice da ascensão, na escala de valores do legislador, da importância atribuída ao bem jurídico que visa a proteger, o agravamento da sanção penal consubstancia a escolha - política - de uma determinada medida normativa voltada ao controle da exposição de crianças e adolescentes aos malefícios que acompanham o uso do tabaco.

A seu turno, a Lei n⿳0 9.294/1996, entre outras providências, dispõe sobre as restrições ao uso e à propaganda de produtos fumígenos. A edição desse diploma representou a escolha, pelo legislador ordinário, de um conjunto específico de medidas que, não limitadas à concretização do comando inscrito no art. 220, $\S^{4^{\circ}}$, da Carta Política - imposição de restrições à propaganda comercial de tabaco - , instituem verdadeira política pública de proteção da saúde por meio do controle do tabaco, abrangendo:

(a) a proibição do uso de cigarros, cigarrilhas, charutos, cachimbos ou qualquer outro produto fumígeno, derivado ou não do tabaco, em recintos coletivos fechados, privados ou públicos (art. $2^{\mathbf{0}}$, caput e $\$ 3^{\circ}$, redação dada pela Lei no $\mathbf{n}^{\mathbf{0}}$ 12.546/2011), especialmente em repartições públicas, hospitais, postos de saúde, salas de aula, bibliotecas, recintos de trabalho coletivo e salas de teatro e cinema ( $\left.\operatorname{art} .2^{\mathbf{0}}, \mathbf{\$} \mathbf{1}^{\mathbf{0}}\right)$, e em aeronaves e veículos de transporte coletivo (art. $2^{\circ}$, §2º , redação dada pela Medida Provisória n⿳0 2.190-34/2001);

(b) a limitação da propaganda comercial desses produtos à simples exposição nos locais de vendas, desde que acompanhada de advertências sobre seus malefícios (art. 3º, caput, redação dada pela Lei $n^{\mathbf{0}}$ 12.546/2011) e ajustada a restrições quanto ao conteúdo veiculado (art. $3^{0}$, $\$ \$ 1^{\mathbf{0}}$ e $2^{0}$, e art. 6 $\left.{ }^{\mathbf{0}}\right)$ - (o art. 79 do Estatuto da Criança e do Adolescente, mais antigo, limitava-se a vedar a propaganda de produtos de tabaco em revistas e publicações destinadas ao público infantojuvenil);

(c) a regulação da apresentação das embalagens, inclusive com a obrigação de veicular mensagens de advertência (art. $3^{\circ}, \$ \S^{\circ}{ }^{\circ}$ a $6^{0}$, com as alterações promovidas pela Medida Provisória no $2.0190-34 / 2001$ e pela Lei no 12.546/2011); e

(d) a restrição das formas pelas quais podem ser comercializados (art. $3^{\mathbf{0}}-\mathbf{A}$, incluído pela Lei $\mathrm{n}^{\mathbf{0}}$ 10.167/2000).

Também o Decreto-lei no $\mathbf{1}$ 1.593/1977, norma equivalente, em grau de hierarquia normativa, à lei ordinária, restringe o exercício da atividade econômica de fabricação de cigarros a empresas cujas instalações atenderem a critérios determinados e mantiverem registro especial na Secretaria da Receita 


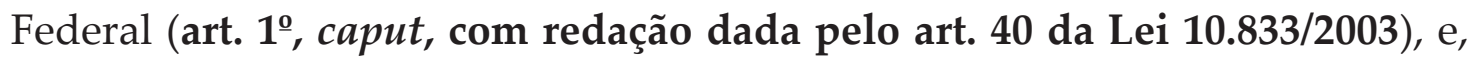
entre outras providências, ainda:

(a) restringe a atividade de fabricação de cigarros a empresas constituídas sob a forma de sociedade e com capital mínimo (art. $1^{0}, \S 1^{\mathbf{0}}$, com redação dada pela Medida Provisória no 2.158-35/2001); e

(b) condiciona a concessão do registro especial à instalação de contadores automáticos da quantidade produzida (art. $1^{\mathbf{0}}, \S 2^{\mathbf{0}}$, com redação dada pela Medida Provisória no 2.158-35/2001).

Em nova iniciativa de natureza legislativa, ainda que se trate de conversão de medida provisória (MP n⿳0 1.602/1997), os arts. 44 a 54 da Lei no 9.532/1997 preveem mais uma série de restrições à comercialização e à importação de cigarros, entre elas:

(a) observância do disposto em regulamento quanto a embalagem, apresentação e outras formas de controle (art. 44);

(b) vedação da importação de cigarros de marca que não seja comercializada no país de origem (art. 46);

(c) exigência de formalidades específicas quanto à constituição da pessoa jurídica, além da inscrição em cadastro especial, para a importação de cigarros (art. 47); e

(d) imposição de preço mínimo de varejo para os cigarros importados (art. $49, \S 1^{\mathrm{o}}$ ).

Vale ressaltar, nesse ponto, que o art. 44 da Lei no 9.532/1997 contempla autorização legislativa expressa para a normatização, mediante regulamento, da embalagem e da apresentação dos cigarros comercializados no país - aí reside o amparo legal à normatização, pelo órgão regulador, das expressões veiculadas nas embalagens e da forma de apresentação do produto.

Pela Mensagem nº 297, de 02 de agosto de 2011, a Presidência da República submeteu ao Congresso Nacional a Medida Provisória no 540/2011, que, entre outras matérias, alterou o regime de tributação dos cigarros (arts. 14 a 20), aumentando para $\mathbf{3 0 0 \%}$ (trezentos por cento) a alíquota do Imposto sobre Produtos Industrializados - IPI incidente sobre o produto cigarro, seja de fabricação nacional ou importado (art. 14), e autorizando o Poder Executivo a fixar preço mínimo de venda de cigarros no varejo (art. 20). Tratou-se, então, de lançar mão de instrumentos de política tributária para influenciar o comportamento do consumidor, em função do aumento de preços, tendo em vista o legítimo e desejável objetivo extrafiscal de impactar positivamente os índices de saúde pública mediante a redução do consumo do tabaco. 
O texto afinal aprovado na Câmara dos Deputados e no Senado resultou na Lei $\mathbf{n}^{\mathbf{0}}$ 12.546/2011, que preservou as referidas medidas extrafiscais dos arts. 14 a 20, presentes no texto original da medida provisória, e, no que interessa ao tema do controle do tabagismo, incorporou o art. 49 do projeto de lei de conversão apresentado pelo relator. É esse dispositivo que confere aos arts. $2^{\circ}$, caput e $\S^{\circ}$, e $3^{\circ}$, caput e $\S \S^{\circ}{ }^{\circ}, 6^{\circ}$ e $7^{\circ}$, da Lei $n^{\circ} 9.294 / 1996$ a sua redação atual, no que preveem, como já mencionado:

(a) proibição do uso de cigarros, cigarrilhas, charutos, cachimbos ou qualquer outro produto fumígeno, derivado ou não do tabaco, em recintos coletivos fechados, privados ou públicos;

(b) a limitação da propaganda comercial desses produtos à simples exposição nos locais de vendas, desde que acompanhada de advertências sobre seus malefícios; e

(c) a regulação da apresentação das embalagens, inclusive com a obrigação de veicular mensagens de advertência.

Vale destacar que há pelo menos quatro projetos de lei atualmente em tramitação no Congresso Nacional tendo por objeto a proibição ou a restrição do uso de aditivos em produtos fumígenos derivados do tabaco.

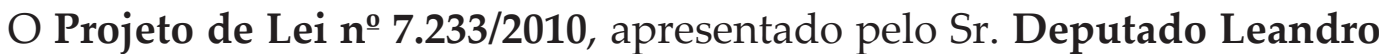
Sampaio (PPS-RJ), tenciona proibir a importação e a comercialização, em todo o território nacional, de qualquer produto fumígeno "aromatizado ou que contenha qualquer tipo de substância aromática que venha mascarar, atenuar o gosto, o cheiro ou os efeitos da nicotina ou de qualquer outro princípio presente nos produtos fumígenos", ficando obrigados os fabricantes de qualquer produto fumígeno a "apresentar à ANVISA informações sobre ingredientes e aditivos acrescentados em seus produtos".

Apensado a ele, o Projeto de Lei no 2.683/2011, de autoria do Sr. Deputado Romero Rodrigues (PSDB-PB), objetiva proibir a produção e a comercialização, em todo o território nacional, de produtos derivados do tabaco contendo aditivos aromatizantes, ficando o órgão de vigilância sanitária do nível federal, que é a própria ANVISA, incumbido de publicar, anualmente, lista especificando os aditivos considerados aromatizantes.

Assim como o PL no 7.233/2010, o PL oํ 2.683/2011 veda apenas os aditivos do tipo aromatizante. No entanto, enquanto aquele alcança qualquer produto fumígeno, derivado ou não do tabaco, este, apesar de não restrito a fumígenos (alcançando, assim, o rapé, o snus e o tabaco de mascar), abrange somente produtos derivados do tabaco. 
Já o Projeto de Lei no 2.901/2011, proposto pelo Sr. Deputado Jerônimo Goergen (PP-RS), e também apensado ao PL $n^{-0} 7.233 / 2010$, visa a proibir a comercialização, em todo o território nacional, de qualquer produto fumígeno, derivado ou não do tabaco, que contenha aditivos que lhe confiram sabor característico, natural ou artificial, assim considerados aqueles que sejam claramente identificáveis pelos consumidores, à exceção de tabaco e mentol. E atribui ao Ministério da Saúde a tarefa de "definir a listagem de aditivos, bem como os respectivos limites quantitativos a partir dos quais os sabores por eles conferidos passam a ser considerados característicos".

A seu turno, o Projeto de Lei do Senado n⿳0 769/2015, de autoria do Senador José Serra, propõe ampliar o alcance das restrições ao uso e à propaganda de produtos fumígenos previstas na Lei no 9.294/1996, mediante, entre outras medidas, a inclusão de preceito com o seguinte teor:

Ficam proibidas a importação e a comercialização no país de produto fumígeno derivado do tabaco que contenha substâncias sintéticas e naturais, em qualquer forma de apresentação, com propriedades flavorizantes ou aromatizantes que possam conferir, intensificar, modificar ou realçar sabor ou aroma do produto.

Como se vê, em discussão no Parlamento a eventual adoção tanto de propostas mais restritivas quanto de alternativas menos abrangentes do que a específica conformação normativa adotada pela ANVISA.

\subsubsection{Sujeição dos produtos fumígenos à regulação setorial exercida pela ANVISA}

Não obstante essas iniciativas legislativas ainda em tramitação, tal não significa, na minha visão, tenha sido editada a RDC no 14/2012 para preencher espaço de suposta anomia com usurpação legislativa. Pelo contrário, entendo que a atuação da ANVISA se legitima, no caso, forte em expressa atribuição. É que, por se tratar de produtos que envolvem risco à saúde pública, os "cigarros, cigarrilhas, charutos e qualquer outro produto fumígeno, derivado ou não do tabaco", estão expressamente submetidos, nos termos do art. $8^{\circ}, \S 1^{\circ}$, X, da Lei $n^{0}$ 9.782/1999, a regime específico e diferenciado de controle e fiscalização sanitária da Agência Nacional de Vigilância Sanitária - ANVISA, à qual 
incumbe, nos termos do caput, regulamentá-los, controlá-los e fiscalizá-los. Transcrevo o dispositivo:

Art. $8^{\circ}$ Incumbe à Agência, respeitada a legislação em vigor, regulamentar, controlar e fiscalizar os produtos e serviços que envolvam risco à saúde pública.

$\S 1^{\circ}$ Consideram-se bens e produtos submetidos ao controle e fiscalização sanitária pela Agência:

[...]

$X$ - cigarros, cigarrilhas, charutos e qualquer outro produto fumígero

(sic), derivado ou não do tabaco; [destaquei]

Da leitura da cuidadosa fórmula textual adotada no art. $8^{\circ}$, caput $\mathrm{e} \$ \mathbf{1}^{\mathrm{o}}, \mathrm{X}$, da Lei $n^{\mathbf{0}}$ 9.782/1999, verifica-se que a Lei $\mathbf{n}^{\mathbf{0}}$ 9.782/1999, no que se refere aos produtos fumígenos derivados do tabaco:

(a) afirma expressamente a sua inclusão no conceito de produtos que envolvem risco à saúde pública;

e (b) submete-os, a partir dessa justificativa, à regulamentação, ao controle e à fiscalização sanitária pela ANVISA.

Tal dispositivo encerra, a meu juízo, inequívoca autorização legislativa para a decisão da ANVISA, formalizada na Resolução da Diretoria Colegiada no 14/2012, de proibir, em caráter geral e primário, produtos ou insumos chamados aditivos - que aumentam a atratividade dos produtos fumígenos derivados do tabaco.

A competência da ANVISA para regulamentar os produtos que envolvam risco à saúde necessariamente inclui a competência para definir, por meio de critérios técnicos e de segurança, os ingredientes que podem e não podem ser usados na fabricação de tais produtos.

Cabe enfatizar, no ponto, que a Resolução da ANVISA impugnada tem por objeto a proibição da adição artificial de substâncias que visem a conferir determinado aroma ou sabor ao cigarro, nada restringindo ou proibindo em relação a qualquer substância, aroma ou sabor naturalmente presente no tabaco.

Insere-se, entre as prerrogativas exercidas legitimamente pela Agência, a edição de atos normativos gerais complementares às leis relacionadas às matérias de sua especialidade. Considerado o todo orgânico do ordenamento jurídico, não há como concluir, com a devida vênia dos que pensam de forma 
diversa, traduza a RDC n⿳ำ 14/2012, de teor eminentemente técnico, criação, $a b$ ovo, de restrição sobre a própria natureza de produto destinado ao consumo, limitada a disciplinar sua forma de apresentação (composição, características etc).

Nesse contexto, o art. $8^{\circ}$, caput e $\S 1^{\circ}$, X, da Lei $n^{\circ}$ 9.782/1999 estabelece regime diferenciado específico de poderes regulatórios a serem exercidos pela ANVISA no tocante aos produtos fumígenos, derivados ou não do tabaco. Daí o suporte legal à RDC 14/2012, observadas as balizas hermenêuticas impostas pela Constituição.

Não é demais ressaltar que, em face de ato normativo editado por agência reguladora com base em exegese do diploma legislativo definidor das suas próprias competências e atribuições, a tônica do exame de constitucionalidade deve ser a deferência da jurisdição constitucional à interpretação empreendida pelo ente administrativo.

A doutrina da deferência administrativa, conhecida como Chevron deference porque sistematizada pela Suprema Corte dos EUA no julgamento do caso Chevron U.S.A., Inc. v. Natural Resources Defense Council, Inc., de 1984, orienta que, uma vez claramente definidos, na lei de regência, as políticas a serem perseguidas, os objetivos a serem implementados e os objetos específicos de tutela, ainda que ausente pronunciamento direto, preciso e não ambíguo do legislador sobre as medidas específicas a adotar, não cabe ao Poder Judiciário, no exercício do controle jurisdicional da exegese conferida por uma Agência ao seu próprio estatuto legal, simplesmente substituíla pela sua própria interpretação da lei. Sendo a lei ambígua com relação à questão específica, a questão a ser decidida pela Corte é se, ao acomodar interesses contrapostos, a solução a que chegou a agência foi devidamente fundamentada e se tem lastro em uma interpretação da lei razoável e compatível com a Constituição. Esse é o ponto.

\subsubsection{A Convenção-Quadro sobre Controle do Uso do Tabaco - CQCT}

Imperioso destacar, nesse contexto, a incorporação, ao ordenamento jurídico brasileiro, da Convenção-Quadro sobre Controle do Uso do Tabaco, a disponibilizar a necessária base material para a proibição dos chamados aditivos, promovida pela RDC n⿳0 14/2012. 
Desde 16 de novembro de 2003, o Brasil é signatário da Covenção-Quadro sobre Controle do Uso do Tabaco - CQCT, a primeira convenção internacional celebrada sob os auspícios da Organização Mundial de Saúde, agência especializada integrante do sistema das Nações Unidas (ONU). A adesão ao tratado foi ratificada em 03 de novembro de 2005 e, em 02 de janeiro de 2006, foi publicado o Decreto Presidencial no 5.658, que deu publicidade interna à ratificação.

A Convenção-Quadro assume como premissa o imperativo da proteção à saúde pública, no sentido de que, em relação ao controle do uso do tabaco,

[...] o Estado se legitima a agir para evitar ou controlar decisões impensadas, que, no caso do tabaco, são potencializadas pelo efeito viciante do produto. Dessa maneira, a possibilidade de limitação a direitos fundamentais é plenamente fundamentada. ${ }^{44}$

No preâmbulo da CQCT, as partes convenentes reconhecem expressamente que "os cigarros e outros produtos contendo tabaco são elaborados de maneira sofisticada de modo a criar e a manter a dependência" e manifestam profunda preocupação com "o elevado aumento do número de fumantes e outras formas de consumo de tabaco entre crianças e adolescentes em todo o mundo, particularmente com o fato de que se começa a fumar em idades cada vez menores".

A CQCT tem como objetivo, afirmado no seu artigo 3, proporcionar uma "referência para as medidas de controle do tabaco, a serem implementadas pelas Partes nos níveis nacional, regional e internacional, a fim de reduzir de maneira contínua e substancial a prevalência do consumo e a exposição à fumaça do tabaco" (destaquei).

O documento proclama, entre seus princípios norteadores (artigo 4, b), "a necessidade de tomar medidas para prevenir a iniciação, promover e apoiar a cessação e alcançar a redução do consumo de tabaco em qualquer de suas formas".

Como obrigações gerais das partes, são previstas, entre outras (artigo 5):

1. Cada Parte formulará, aplicará e atualizará periodicamente e revisará estratégias, planos e programas nacionais multissetoriais integrais

44 VEDOVATO, Luís Renato. A Convenção-Quadro sobre Controle do Uso do Tabaco: consequências para o ordenamento jurídico brasileiro. In: HOMSI, Clarissa Menezes (Coord.). O controle do tabaco e o ordenamento jurídico brasileiro. Rio de Janeiro: Editora Lumen Juris, 2011. 
de controle do tabaco, de conformidade com as disposições da presente Convenção e dos protocolos aos quais tenha aderido.

2. Para esse fim, as Partes deverão, segundo as suas capacidades:

(a) estabelecer ou reforçar e financiar mecanismo de coordenação nacional ou pontos focais para controle do tabaco; e

(b) adotar e implementar medidas legislativas, executivas, administrativas e/ou outras medidas e cooperar, quando apropriado, com outras Partes na elaboração de políticas adequadas para prevenir e reduzir o consumo de tabaco, a dependência da nicotina e a exposição à fumaça do tabaco.

3. Ao estabelecer e implementar suas políticas de saúde pública relativas ao controle do tabaco, as Partes agirão para proteger essas políticas dos interesses comerciais ou outros interesses garantidos para a indústria do tabaco, em conformidade com a legislação nacional. [destaquei]

Especificamente no tocante à regulamentação do conteúdo dos produtos de tabaco, dispõe o artigo 9 da Convenção que:

A Conferência das Partes, mediante consulta aos organismos internacionais competentes, proporá diretrizes para a análise e a mensuração dos conteúdos e emissões dos produtos de tabaco, bem como para a regulamentação desses conteúdos e emissões. Cada Parte adotará e aplicará medidas legislativas, executivas e administrativas, ou outras medidas eficazes aprovadas pelas autoridades nacionais competentes, para a efetiva realização daquelas análises, mensuração e regulamentação. [destaquei]

Não se desconhece que uma Convenção-quadro é assim predicada justamente por se tratar de instrumento limitado, em seu escopo, a estabelecer um quadro, uma base comum para orientar a cooperação internacional sobre determinado assunto, o que tipicamente ocorre quando os Estados convenentes, embora concordem sobre a necessidade de abordar uma questão em linhas gerais, não chegam ao consenso sobre os detalhes para uma efetiva regulação:

[...] o termo convenção-quadro não é um termo jurídico técnico. Uma vez que convenções-quadro variam consideravelmente com respeito ao 
conteúdo, ao grau e à forma das obrigações substantivas e ao desenho institucional, não há concordância sobre uma definição legal mas apenas uma coleção de elementos comuns à maioria das convenções-quadro. Pode-se argumentar, a partir da função das convenções-quadro, que elas estabelecem um sistema geral de governança, e não obrigações detalhadas. Portanto, de um ponto de vista teorético, pode-se dizer que a característica específica de uma convenção-quadro típica é a formulação dos objetivos de um regime, enquanto deixa regras mais detalhadas e a definição de alvos específicos para acordos paralelos ou subsequentes entre as partes. ${ }^{45}$

Convenções-quadro, de um modo geral, codificam consensos amplos e princípios básicos, diferindo as negociações mais difíceis, sobre regras específicas de observância compulsória, para protocolos a serem celebrados no marco institucional da convenção mãe. O primeiro, e até o momento único, protocolo sob o signo da CQCT, é o Protocolo para a Eliminação do Comércio Ilícito de Produtos de Tabaco, adotado em novembro de 2012.

Tanto é assim que as recomendações contidas na Convenção-Quadro a respeito da regulação do conteúdo dos produtos de tabaco têm sido interpretadas de diferentes maneiras em jurisdições diversas.

Quando sob a égide da Diretiva 2001/37/CE, que não veiculava norma expressa sobre ingredientes e aditivos em produtos de tabaco, permaneciam significativas diferenças, entre os países-membros da União Europeia, de requerimentos exigidos para o uso de aditivos. Se, de um lado, Noruega e Holanda, por exemplo, não dispunham de legislação doméstica proibindo ou permitindo o uso de aditivos nos produtos derivados do tabaco, de outro, Alemanha e Bélgica já usavam listas de ingredientes proibidos e permitidos, baseadas primariamente na legislação sobre aditivos aprovados para uso alimentar. ${ }^{46}$

Apenas com a aprovação da Diretiva 2014/40/UE do Parlamento Europeu e do Conselho da União Europeia relativa à aproximação das disposições legislativas, regulamentares e administrativas dos Estados-Membros no que respeita ao fabrico, apresentação e venda de produtos do tabaco

45 MATZ-LÜCK, Nele. Framework conventions as a regulatory tool. Goettingen Journal of International Law 1 (2009) 3, 439-458 (Tradução livre).

46 TALHOUT, R. Reporting and regulation of tobacco ingredients: a comparison of the Netherlands with other countries. RIVM Report 340610004. Dutch: 2012. 
e produtos afins, e que substituiu a Diretiva de 2001, é que veio a ser harmonizado o direito comunitário no tocante à implementação, entre outras medidas regulatórias, de restrições ao uso de aditivos.

No próprio âmbito da Organização Mundial de Saúde, idealizadora da Convenção-Quadro sobre Controle do Uso do Tabaco, não há definição de parâmetros para o uso de aditivos nos produtos de tabaco.

Vale ressaltar que a ratificação do Brasil à CQCT foi acompanhada pelas seguintes declarações interpretativas:

O Brasil interpreta que, no contexto dos parágrafos 15 e 16 do preâmbulo, e dos Artigos 4(6), 17 e 26(3) da CQCT da OMS, não há proibição à produção do tabaco ou restrição a políticas nacionais de apoio aos agricultores que atualmente se dedicam a essa atividade. $[\ldots]$

Por fim, o Brasil também declara que não apoiará nenhuma proposta que visem utilizar a CQCT da OMS como um instrumento para práticas discriminatórias ao livre comércio.

Longe de ser autoaplicável, o texto é expresso em reconhecer que as medidas ali propostas não dispensam, quando o caso, elaboração legislativa ou de outra natureza, no âmbito doméstico. Rende tributo, assim, à soberania e às constituições dos Estados convenentes. A adoção da CQCT em absoluto significa, e nem poderia, um atropelamento da soberania e das instituições democráticas dos Estados-membros.

Embora a redação empregada na CQCT revele a tessitura aberta e o caráter recomendativo e não impositivo da maior parte das suas disposições, não se pode desconsiderar que ela estabelece linhas mestras para nortear a elaboração da legislação doméstica sobre o controle do tabaco, resultando, da sua adoção, o compromisso dos Estados parte de orientar a política doméstica no sentido de que sejam alcançadas as finalidades consagradas na Convenção.

Ao ratificar a Convenção-Quadro, o Estado Brasileiro se comprometeu, é o que exsurge da leitura do seu texto, a tomar as medidas legislativas, executivas ou administrativas adequadas aos fins estabelecidos: prevenir e reduzir o consumo de tabaco, a dependência da nicotina e a exposição à fumaça do tabaco. Embora o texto da CQCT, incorporado ao ordenamento jurídico brasileiro, não vincule o Estado à adoção de uma específica matriz regulatória quanto ao conteúdo dos produtos derivados do tabaco, a adesão 
do Brasil à CQCT não apenas ampara como estimula, no plano internacional, a adoção das medidas necessárias pelas autoridades domésticas competentes.

Na Quarta Conferência das Partes (COP4), mecanismo previsto no artigo 23 da Convenção-Quadro para o Controle do Tabaco para orientar e avaliar a sua implementação, foi produzido o documento intitulado Diretrizes Parciais para Implementação dos Artigos 9 e 10 da Convenção-Quadro para o Controle do Tabaco da OMS (Regulamentação do Conteúdo dos Produtos de Tabaco e Regulamentação da Divulgação das Informações sobre os Produtos de Tabaco), com o objetivo de "apoiar as Partes no desenvolvimento de uma regulação eficaz dos produtos de tabaco".

O documento reconhece que "cada parte deve, quando aprovadas pelas autoridades nacionais competentes, adotar e implementar medidas legislativas, executivas e administrativas, ou outras medidas eficazes para a análise e a medição do conteúdo e das emissões de produtos do tabaco e para a regulamentação desses conteúdos e emissões" e recomenda que "as Partes deveriam considerar dar à autoridade responsável por questões de controle do tabaco a responsabilidade, ou, no mínimo, o poder de contribuir para a aprovação, adoção e implementação das medidas [...] mencionadas".

Nele, a fim de conferir eficácia ao artigo 9 da Convenção, os Estados parte são incentivados a adotar medidas para "regulamentar, proibindo ou restringindo ingredientes que possam ser usados para aumentar a palatabilidade dos produtos de tabaco", além de normatizar o uso dos "ingredientes indispensáveis para a fabricação de produtos de tabaco e não vinculados à atratividade".

As diretrizes de implementação da CQCT elaboradas por grupo de trabalho designado em Conferência das próprias partes do tratado, e que podem ser tidas como interpretação autêntica das suas normas, autorizam a conclusão de que a incorporação da CQCT ao direito interno, embora não vinculante, fornece um standard de razoabilidade para aferição dos parâmetros adotados na RDC n⿳0 $14 / 2012$ pela ANVISA.

Nessa ordem de ideias, os critérios técnicos adotados pela ANVISA para regular, com espeque na competência atribuída pelos arts. $7^{\mathbf{0}}$, III, e $\mathbf{8}^{\mathbf{0}}, \mathbf{\$}^{\mathbf{0}}{ }^{\mathbf{0}}, \mathbf{X}$, Lei n⿳⺈ 9.782/1999, a composição dos produtos derivados do tabaco encontram, nos standards definidos na Convenção-Quadro para o Controle do Tabaco, senão uma base normativa material, pelo menos uma fonte de respaldo da sua razoabilidade e proporcionalidade. 


\subsubsection{Nota sobre a restrição de direitos fundamentais no Estado democrático de direito}

O sentido constitucional da livre-iniciativa de modo algum exclui a possibilidade de sua conformação mediante legítima atividade normativa e reguladora do Estado. In casu, as restrições ao direito fundamental da liberdade de iniciativa atribuídas à RDC $\mathrm{n}^{-}$14/2012 traduzem imposições do complexo normativo que a ampara, em nome de outro direito fundamental - a saúde.

Entendo que a limitação ora verificada no âmbito de eficácia de normas constitucionais definidoras de direitos fundamentais, no caso a livre-iniciativa, de modo, repito, a conformá-las com os demais postulados constitucionais direito à saúde - , preserva satisfatoriamente o seu núcleo essencial.

No cumprimento do seu dever de implementação das políticas públicas do Estado, não raro o Administrador intervém ativamente na sociedade, e não sem exercer certa dose de criatividade. E, de fato, como assentado acima, constitui um traço familiar e inescapável das democracias modernas a delegação de poderes legislativos limitados ao Poder Executivo. ${ }^{47}$

Nada disso, no entanto, o transforma, Poder Executivo, via agência reguladora, em legislador. Subsidiada por significativos e numerosos insumos técnicos, indicativos dos efeitos negativos, do ponto de vista da saúde pública, do uso de aditivos na fabricação de produtos fumígenos derivados do tabaco, a veiculação da proibição de que o produto fumígeno derivado do tabaco tenha o seu sabor ou aroma de qualquer modo alterado assume conotação estritamente técnica.

A atuação normativa da ANVISA, no caso, se acomoda adequadamente ao propósito claro do legislador de promover o controle do tabaco e a proteção da saúde, sem incorrer em proibição da comercialização de produto lícito, o que, aí sim, extrapolaria a sua competência regulatória.

Embora não lhe caiba a formulação, como já salientei, à ANVISA compete a condução da política nacional de saúde (arts. $2^{\circ}$, $\S 1^{\circ}$, I, e $7^{\circ}$ da Lei no 9.782/1999). Ao proscrever determinadas estratégias mercadológicas e tecnológicas voltadas à ampliação da base de consumidores de um produto causador de dependência, ela o faz amparada em prévias escolhas políticas, consoante já exposto.

47 HART, Herbert. O conceito de direito. 2. ed. Lisboa: Fundação Calouste Gulbekian, 2002. 


\subsubsection{Contribuição do direito comparado}

O estudo do direito comparado de Estados democráticos corrobora o raciocínio aqui desenvolvido.

Nos Estados Unidos da América, com a aprovação, em 22 de junho de 2009, do Family Smoking Prevention and Tobacco Control Act (Lei de Prevenção do Fumo na Família e Controle do Tabaco, em tradução livre), o Congresso dos Estados Unidos alterou o Federal Food, Drug and Cosmetic Act - FFDCA, lei de regência da segurança sanitária dos setores de alimentos, drogas e cosméticos, de 1938, para, entre outras medidas, (i) proibir cigarros com sabores outros que não tabaco ou mentol; (ii) atribuir à Food and Drug Administration $F D A$, agência reguladora federal que serviu de modelo para congêneres mundo afora, inclusive a ANVISA, competência específica para dispor sobre o conteúdo dos produtos de tabaco. Eis o teor do dispositivo, em tradução livre:

Seção 907 (a), (1), (A) Regras especiais para cigarros:

[...] um cigarro ou qualquer das suas partes componentes (incluindo o tabaco, filtro, ou papel) não deverá conter, como constituinte (incluindo constituinte da fumaça) ou aditivo, um sabor natural ou artificial (outro que não tabaco ou mentol) ou uma erva ou tempero, incluindo morango, uva, laranja, cravo, canela, abacaxi, baunilha, coco, alcaçuz, cacau, chocolate, cereja, ou café, que seja um sabor caracterizante do produto de tabaco ou da fumaça do tabaco. Nada neste subparágrafo deve ser interpretado para limitar a autoridade do Secretário de tomar medidas com base nesta seção ou outras seções desta Lei aplicáveis ao mentol ou qualquer sabor natural ou artificial, erva, ou tempero não especificado neste subparágrafo.

Na União Europeia, restrições à utilização de aditivos no fabrico de produtos de tabaco foram implementadas por meio de Diretiva do Parlamento Europeu e do Conselho da União Europeia, ato legislativo ordinário do direito comunitário europeu. Ao aprovar, em 29.4.2014, a Diretiva 2014/40/UE, relativa à aproximação das disposições legislativas, regulamentares e administrativas dos Estados-Membros no que respeita ao fabrico, à apresentação e à venda de produtos do tabaco e produtos afins, o legislador europeu, em suma: 
(a) proibiu a comercialização, nos Estados-Membros, de produtos do tabaco com aroma distintivo (artigo $\mathbf{7}^{\mathbf{0}}, \mathbf{1}$ ), quando apresentados sob a forma de cigarros ou tabaco de enrolar (artigo $7^{0}, 12$ );

(b) permitiu a utilização de aditivos essenciais para o fabrico de produtos do tabaco, aludindo expressamente ao açúcar para substituir o açúcar perdido durante o processo de cura, desde que não resultem num produto com aroma distintivo e não aumentem em grau significativo ou mensurável a toxidade, o potencial de criação de dependência ou as propriedades cancerígenas, mutagênicas ou tóxicas para a reprodução dos produtos do tabaco (artigo $\left.\mathbf{7}^{\mathbf{0}}, \mathbf{1}\right)$;

(c) proibiu a comercialização de produtos do tabaco contendo: vitaminas ou outros aditivos que criem a impressão de que um produto do tabaco possui benefícios para a saúde ou apresenta riscos reduzidos para a saúde; cafeína, taurina ou outros estimulantes associados a energia e vitalidade; aditivos que confiram cor às emissões; facilitadores da inalação ou da absorção de nicotina; e aditivos que, na sua forma sem combustão, têm, eles próprios, propriedades cancerígenas, mutagênicas ou tóxicas para a reprodução (artigo $\left.7^{0}, 6\right)$;

(d) proibiu a comercialização de cigarros e tabaco de enrolar (mas permitiu para produtos do tabaco consumidos sob outras formas) contendo aromatizantes em componentes tais como filtros, papéis, embalagens, cápsulas ou outras características técnicas, de modo a modificar o odor ou o sabor dos produtos do tabaco ou a intensidade do seu fumo (artigo 7으, 7 e 12);

(e) proibiu aditivos em quantidades que aumentem em grau significativo ou mensurável o efeito tóxico ou de dependência de um produto do tabaco ou as suas propriedades cancerígenas, mutagênicas ou tóxicas para a reprodução na fase do consumo (artigo 70ㅜ, 9); e

(f) excluiu o tabaco para uso oral (snus, tabaco de mascar) da hipótese de incidência das proibições veiculadas (artigo $\left.7^{\mathbf{0}}, 15\right)$.

O Tribunal de Justiça da União Europeia, instância judicial suprema daquela comunidade de Estados, reconheceu a validade do artigo $7^{\mathbf{0}}$ da Diretiva 2014/40/UE ao julgar o reenvio prejudicial C-547/14. 


\subsubsection{Constitucionalidade da Resolução da Diretoria Colegiada n? 14/2012 da ANVISA}

Concluo, Sra. Presidente, reafirmando que o prejuízo à saúde associado ao consumo de produtos fumígenos de tabaco é intrinsecamente elevado. A ANVISA justifica a proibição pretendida aludindo ao incremento no risco atribuído à maior atratividade conferida pelas substâncias banidas ao produto. Trata-se da asserção singela e empiricamente demonstrada de que, adicionadas aos produtos fumígenos, substâncias como açúcar, frutas, mel e temperos, entre outras, impulsionam a iniciação do seu consumo ao tornálos mais atrativos. De toda sorte, com ou sem aditivos, continua presente a nicotina, substância de incontroversa nocividade à saúde, causadora de dependência física e psicológica, e componente do próprio tabaco. A nicotina, por si só, justifica a existência de todo o rígido aparato regulatório incidente sobre os produtos derivados do tabaco, cuja instrumentalização, respeitados os limites formais e materiais impostos pela Constituição, se mostra não só legítima como necessária.

As restrições da Resolução da Diretoria Colegiada n⿳0 14/2012 da ANVISA à produção, à comercialização e à importação de produtos derivados do tabaco estão, a meu juízo, devidamente amparadas no ordenamento vigente, em particular, repito, nos arts. $7^{0}$, III, e $8^{\circ}, \S^{\circ} 1^{\circ}, X$, da Lei $\mathbf{n}^{0}$ 9.782/1999. Limitada a expressar critérios técnicos para a fabricação e circulação de um produto de interesse para a saúde, a medida não tem o condão de alterar a sua natureza ou redefinir características elementares da sua identidade.

Nesses termos, julgo improcedente o pedido sucessivo, declarando a constitucionalidade dos arts. $6^{0}$, $7^{0}$ e 9o da Resolução da Diretoria Colegiada (RDC) nº 14/2012 da ANVISA.

\section{Conclusão}

Ante o exposto, julgo improcedentes os pedidos deduzidos na presente ADI.

É como voto. 